\title{
Stereoselective Cyclization and Pyramidal Inversion Strategies for P-Chirogenic Phospholane Synthesis
}

\author{
Garrett Hoge
}

\section{Supporting Information}

Materials and Methods. All reactions and manipulations were performed under nitrogen in standard laboratory glassware. Rhodium complex recrystallization and asymmetric hydrogenation were performed in a nitrogen filled glovebox. THF (anhydrous, 99.9\%), acetonitrile (anhydrous, 99.8\%), ether (anhydrous, 99.8\%), methyl alcohol (anhydrous, 99.8\%), and dichloromethane (anyhydrous, 99.8\%) were obtained from Aldrich Chemical Co. Thionyl chloride (99.5\%), ruthenium (III) chloride hydrate (99.98\%), sodium periodate $(99 \%)$, and $\mathrm{n}-\mathrm{BuLi}(2.5 \mathrm{M}$ in hexanes) were obtained from Aldrich Chemical Co. Bis(1,5cyclooctadiene)rhodium (I) trifluoromethanesulfonate (99\%), 1,2-Bis(phosphino)benzene (98+\%), 1,2Bis(phosphino)ethane (99\%), and Phenylphosphine (99\%) were obtained from Strem Chemicals, Inc. Hydrogen gas was used from a lecture bottle supplied by Specialty Gas. Hydrogenations were performed in a Griffin-Worden pressure vessel supplied by Kimble/Kontes.

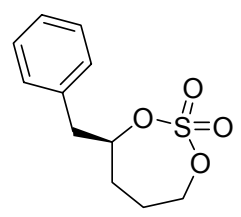

$5 c$

Preparation of (4S)-4-benzyl-1,3,2-dioxathiepane 2,2-dioxide (5c). To a $250 \mathrm{~mL}$ round bottom flask was dissolved (S)-5-Phenyl-pentane-1,4-diol, 4c, (8.97 g, $49.8 \mathrm{mmole})$ in $150 \mathrm{~mL} \mathrm{CH}_{2} \mathrm{Cl}_{2}$ and then placed under $\mathrm{N}_{2}$ and cooled to $0{ }^{\circ} \mathrm{C}$. Thionyl chloride $(4.54 \mathrm{~mL}, 62.2 \mathrm{mmole})$ was added in one portion via syringe. No exotherm was observed. The reaction was warmed to room temperature and stirred for 30 minutes. Gaseous $\mathrm{HCl}$ was observed evolving from the solution. The solution was light brown. The reaction was then placed in an oil bath and refluxed open to air for 15 hours. The $\mathrm{CH}_{2} \mathrm{Cl}_{2}$ was then removed on a rotary evaporator. The light brown residue was redissolved in $150 \mathrm{~mL} \mathrm{CH}_{2} \mathrm{Cl}_{2}$ and $150 \mathrm{~mL} \mathrm{CH}_{3} \mathrm{CN}$. To this solution was added $300 \mathrm{~mL} \mathrm{H} \mathrm{H}_{2} \mathrm{O}$ and then the solution was cooled to $0{ }^{\circ} \mathrm{C}$ and stirred in air. $\mathrm{RuCl}_{3} \cdot \mathrm{xH}_{2} \mathrm{O}$ $(0.112 \mathrm{~g}, 0.498 \mathrm{mmole})$ was added in one portion and then sodium periodate $(21.3 \mathrm{~g}, 99.5 \mathrm{mmole})$ was added portionwise until it became apparent that the reaction would not exotherm. The reaction was stirred for 5 hours during which it turned from light brown to black. The reaction was transferred to a separatory funnel and the black bottom layer was separated. The top aqueous layer was then extracted with $300 \mathrm{~mL}$ ethyl ether. The ether layer was combined with the black bottom layer and the resulting solution was filtered through a short plug of Si gel washing with ethyl ether to produce a light yellow solution. The filtration was needed to remove Ru salts. Volatiles were removed on a rotary evaporator leaving a light green oil. The oil recrystallized upon standing for 20 minutes. A small amount of ethyl ether was added and then the crystals were collected and washed with hexane producing $4.83 \mathrm{~g}$ of white crystalline product. A second crop formed in the mother liquor after addition of hexane (from the washes). These crystals were collected and weighed $3.30 \mathrm{~g}$. The white crystalline product was stable in air for $>6$ months. If Ru salts were still apparent in the crystalline product (as observed by the appearance of green solids after redissolving the crystals in THF) the crystals should be redissolved in THF and filtered again through a short plug of silica gel and then recrystallized a second time. $\mathrm{mp} 80.3-81.4{ }^{\circ} \mathrm{C} ;[\alpha]_{\mathrm{D}}^{24}=+16.0^{\circ}$ (c 1.0, CHCl3); ${ }^{1} \mathrm{H} \mathrm{NMR}\left(400 \mathrm{MHz} \mathrm{CDCl}_{3}\right)$ $\delta 1.97(\mathrm{~m}, 4 \mathrm{H}) 2.92(\mathrm{dd}, J=13.91,7.08 \mathrm{~Hz}, 1 \mathrm{H}) 3.14(\mathrm{dd}, J=14.03,6.22 \mathrm{~Hz}, 1 \mathrm{H}) 4.34(\mathrm{~m}, J=12.08,3.42$, $3.29 \mathrm{~Hz}, 1 \mathrm{H}) 4.45(\mathrm{~m}, J=11.83,11.83,1.46 \mathrm{~Hz}, 1 \mathrm{H}) 4.83(\mathrm{~m}, 1 \mathrm{H}) 7.22(\mathrm{~m}, 2 \mathrm{H}) 7.29(\mathrm{~m}, 3 \mathrm{H}) ;{ }^{13} \mathrm{C} \mathrm{NMR}$ $(101 \mathrm{MHz}, \mathrm{CDCl} 3) \delta 27.41,32.02,41.79,71.91,85.19,127.45,128.95,129.73,135.57$. Anal. Calcd for $\mathrm{C}_{11} \mathrm{H}_{14} \mathrm{O}_{4} \mathrm{~S}: \mathrm{C}, 54.53 ; \mathrm{H}, 5.82$. Found: C, 54.60; H, 5.77. 


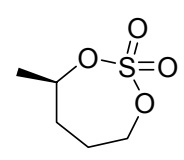

$5 a$

Preparation of (4R)-4-methyl-1,3,2-dioxathiepane 2,2-dioxide (5a). Prepared in a similar procedure to that of cyclic sulfate 5c. The resulting oil was chromatographed over silica gel ( $25 \%$ ethyl acetate/hexanes) providing 5a in $48 \%$ yield. bp $117.2^{\circ} \mathrm{C} ;[\alpha]^{24}{ }_{\mathrm{D}}=-6.1^{\circ}\left(\mathrm{c} 1.0, \mathrm{CHCl}_{3}\right) ;{ }^{1} \mathrm{H} \mathrm{NMR}\left(400 \mathrm{MHz}, \mathrm{CDCl}_{3}\right) \delta 1.43$ (d, $J=6.34 \mathrm{~Hz}, 3 \mathrm{H}) 1.94(\mathrm{~m}, 3 \mathrm{H}) 2.11(\mathrm{~m}, 1 \mathrm{H}) 4.35(\mathrm{~m}, 1 \mathrm{H}) 4.44(\mathrm{td}, J=11.90,1.34 \mathrm{~Hz}, 1 \mathrm{H}) 4.79(\mathrm{~m}$, $J=15.10,6.30,6.30,3.05 \mathrm{~Hz}, 1 \mathrm{H}) ;{ }^{13} \mathrm{C}$ NMR $\left(101 \mathrm{MHz}, \mathrm{CDCl}_{3}\right) \delta 21.65,27.42,34.68,72.01,82.06$. HRMS (EI): $(\mathrm{M}+\mathrm{H})^{+} 167.0337\left((\mathrm{M}+\mathrm{H})^{+}\right.$, exact mass calcd for $\left.\mathrm{C}_{5} \mathrm{H}_{11} \mathrm{O}_{4} \mathrm{~S}: 167.0378\right)$.

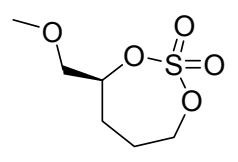

$5 b$

Preparation of (4S)-4-(methoxymethyl)-1,3,2-dioxathiepane 2,2-dioxide (5b). Prepared in a similar manner to cyclic sulfate 5c. The resulting oil was chromatographed over silica gel ( $25 \%$ ethyl acetate/hexanes) providing $5 \mathbf{c}$ in $53 \%$ yield. $\mathrm{mp} 60.3-60.8^{\circ} \mathrm{C} ;[\alpha]^{24}=-9.8^{\circ}\left(\mathrm{c} 1.0, \mathrm{CHCl}_{3}\right) ; 1 \mathrm{H} \mathrm{NMR}(400$ $\left.\mathrm{MHz}, \mathrm{CDCl}_{3}\right) \delta \mathrm{ppm} 2.00(\mathrm{~m}, 3 \mathrm{H}) 2.10(\mathrm{~m}, 1 \mathrm{H}) 3.39(\mathrm{~d}, J=2.68 \mathrm{~Hz}, 3 \mathrm{H}) 3.50(\mathrm{dd}, J=10.86,4.76 \mathrm{~Hz}, 1 \mathrm{H})$ $3.59(\mathrm{dd}, J=10.74,5.37 \mathrm{~Hz}, 1 \mathrm{H}) 4.38(\mathrm{~m}, 1 \mathrm{H}) 4.46(\mathrm{td}, J=11.71,1.46 \mathrm{~Hz}, 1 \mathrm{H}) 4.71(\mathrm{~m}, 1 \mathrm{H}) ; 13 \mathrm{C}$ NMR $\left(101 \mathrm{MHz}, \mathrm{CDCl}_{3}\right) \delta \mathrm{ppm} 27.14,29.50,59.61,72.12,73.65,82.61$. Anal. Calcd for $\mathrm{C}_{6} \mathrm{H}_{12} \mathrm{O}_{5} \mathrm{~S}: \mathrm{C}, 36.73 ; \mathrm{H}$, 6.16. Found: C, 36.74; H, 6.01.

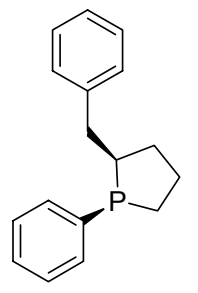

9c

Preparation of (1R, 2R)-1-Phenyl-2-benzylphospholane (9c). To a $25 \mathrm{~mL}$ round bottom flask equipped with a magnetic stirring bar was added phenylphosphine $(0.300 \mathrm{~g}, 2.73 \mathrm{mmole})$. To the flask was added 10 $\mathrm{mL}$ THF via syringe and the reaction was placed under nitrogen and cooled to $0{ }^{\circ} \mathrm{C}$. To the solution was then added $\mathrm{n}$-BuLi ( 1.0 equiv, $1.0 \mathrm{~mL}$ of a $2.5 \mathrm{M}$ solution in hexanes) and the reaction was stirred 1 hour at $0{ }^{\circ} \mathrm{C}$. The reaction solution was yellow indicative of phosphine anion formation. A solution of cyclic sulfate in $5 \mathrm{~mL}$ THF was then added via syringe. The reaction was stirred 30 minutes at $0{ }^{\circ} \mathrm{C}$ and then 30 minutes at room temperature. The reaction was cooled back down to $0{ }^{\circ} \mathrm{C}$ and then $\mathrm{n}-\mathrm{BuLi}(1.15$ equiv, $1.25 \mathrm{~mL}$ of a $2.5 \mathrm{M}$ solution in hexanes) was added dropwise over five minutes. The reaction was stirred 30 minutes at 0 ${ }^{\circ} \mathrm{C}$ and then warmed to room temperature and stirred 45 minutes. The reaction was quenched with $1 \mathrm{~mL}$ $\mathrm{MeOH}$ to produce a white chunky solution. The volatiles were removed invacuo and then the white oily solid was triturated with ethyl ether and then filtered to remove the sulfate salts. The solvent in the filtrate was then removed invacuo producing $603 \mathrm{mg}(82 \%)$ of a clear oil. ${ }^{31} \mathrm{P}$ NMR $\left(162 \mathrm{MHz}, \mathrm{CDCl}_{3}\right) \delta \mathrm{ppm}-7.0$ (s). 
Phospholane 9c was converted to its phosphine borane derivative for characterization purposes via the following procedure:

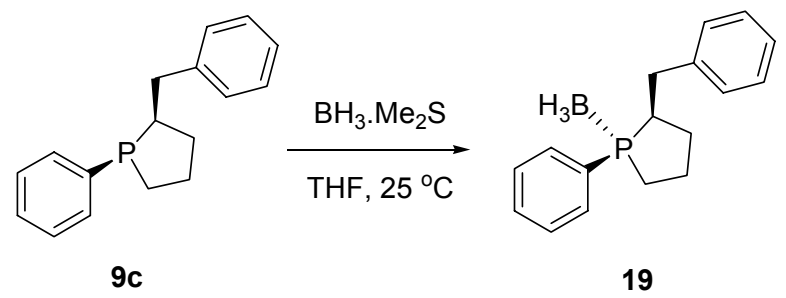

(1R, 2R)-1-Phenyl-2-benzylphospholaneborane (19). Phospholane 9c was dissolved in $10 \mathrm{~mL}$ THF under nitrogen and stirred with a magnetic stir bar. To this solution was added $\mathrm{BH}_{3} \cdot \mathrm{Me}_{2} \mathrm{~S}(0.273 \mathrm{~mL}$ of a $10.0 \mathrm{M}$ solution) via syringe. The reaction was stirred for 30 minutes and then the volatiles were removed on a rotary evaporator to produce a white solid. The white solid was recrystallized from hot $15 \%$ ethyl acetate in hexanes producing $440 \mathrm{mg}(61 \%$ from $\mathbf{5 c})$ of white crystals. $\mathrm{mp} 94.2-95.1^{\circ} \mathrm{C} ;[\alpha]^{20}{ }_{\mathrm{D}}=-1.3^{\circ}(\mathrm{c} 1.0, \mathrm{CHCl} 3)$; ${ }^{1} \mathrm{H}$ NMR $\left(400 \mathrm{MHz}, \mathrm{CDCl}_{3}\right) \delta 0.86(\mathrm{~m}, 3 \mathrm{H}) 1.55(\mathrm{~m}, 1 \mathrm{H}), 1.79(\mathrm{~m}, 1 \mathrm{H}), 2.04(\mathrm{~m}, 2 \mathrm{H}), 2.24(\mathrm{~m}, 3 \mathrm{H})$, $2.40(\mathrm{~m}, 1 \mathrm{H}), 2.67(\mathrm{~m}, 1 \mathrm{H}), 6.98(\mathrm{~m}, 2 \mathrm{H}), 7.18(\mathrm{~m}, 3 \mathrm{H}), 7.51(\mathrm{~m}, 3 \mathrm{H}), 7.73(\mathrm{~m}, 2 \mathrm{H}) ;{ }^{13} \mathrm{C}$ NMR $(101$ $\left.\mathrm{MHz}, \mathrm{CDCl}_{3}\right) \delta 25.13,25.46$ (d, $\left.J=36.85 \mathrm{~Hz}\right), 33.73,35.82,42.24,126.54,127.74$ (d, $\left.J=43.76 \mathrm{~Hz}\right), 128.67$ (d, $J=18.43 \mathrm{~Hz}), 128.92$ (d, $J=9.21 \mathrm{~Hz}), 128.96,131.75$ (d, $J=2.30 \mathrm{~Hz}), 133.25$ (d, $J=8.45 \mathrm{~Hz}), 140.04$ (d, $J=10.75 \mathrm{~Hz}) ;{ }^{31} \mathrm{P}$ NMR $\left(162 \mathrm{MHz}, \mathrm{CDCl}_{3}\right) \delta 32.76$. Anal. Calcd for $\mathrm{C}_{17} \mathrm{H}_{22} \mathrm{BP}: \mathrm{C}, 76.15 ; \mathrm{H}, 8.27$. Found: C, $73.16 ; \mathrm{H}, 8.29$.<smiles>CC1CCCP1c1ccccc1</smiles>

Preparation of (1R, 2S)-1-Phenyl-2-methylphospholane (9a). Prepared in a similar manner to phospholane 9c. ${ }^{31} \mathrm{P}$ NMR $\left(162 \mathrm{MHz}, \mathrm{CDCl}_{3}\right) \delta \mathrm{ppm}-5.80(\mathrm{~s})$.

Phospholane 9a was converted to its phosphine borane derivative for characterization purposes via the following procedure:<smiles>C[C@H]1CCCP1c1ccccc1</smiles>

$9 a$

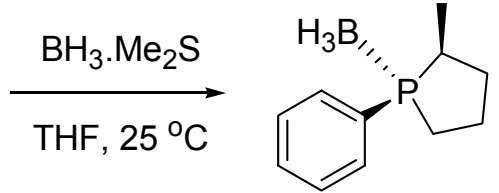

20

(1R, 2S)-1-Phenyl-2-methylphospholaneborane (20). Prepared in a similar procedure to that of 19. The resulting oily diastereomers were inseparable via column chromatography over silica gel. ${ }^{1} \mathrm{H}$ NMR (400 $\left.\mathrm{MHz}, \mathrm{CDCl}_{3}\right) \delta 0.84(\mathrm{~m}, 3 \mathrm{H}) 0.83(\mathrm{dd}, J=14.41,6.59 \mathrm{~Hz}, 3 \mathrm{H}) 1.53(\mathrm{~m}, 1 \mathrm{H}) 1.85(\mathrm{~m}, 1 \mathrm{H}) 2.19(\mathrm{~m}, 5 \mathrm{H})$ $7.48(\mathrm{~m}, 3 \mathrm{H}) 7.68(\mathrm{~m}, 2 \mathrm{H}) ;{ }^{13} \mathrm{C} \mathrm{NMR}\left(101 \mathrm{MHz}, \mathrm{CDCl}_{3}\right) \delta 14.06,25.09$ (d, $\left.J=36.08 \mathrm{~Hz}\right), 34.64,35.07$ (d, $J=36.08 \mathrm{~Hz}), 36.10,128.79(\mathrm{~m}, J=9.21 \mathrm{~Hz}), 131.48,133.09(\mathrm{~d}, J=8.44 \mathrm{~Hz}) ;{ }^{31} \mathrm{P}$ NMR $\left(162 \mathrm{MHz}, \mathrm{CDCl}_{3}\right) \delta$ $33.84(\mathrm{~m})$. HRMS (EI): $\left(\mathrm{M}-\mathrm{BH}_{3}+\mathrm{H}\right)^{+} 179.1136\left(\left(\mathrm{M}-\mathrm{BH}_{3}+\mathrm{H}\right)^{+}\right.$, exact mass calcd for $\mathrm{C}_{11} \mathrm{H}_{16} \mathrm{P}$ : 179.0990). 


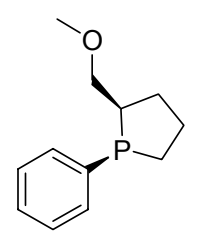

9b

Preparation of (1R, 2R)-1-Phenyl-2-(methoxymethyl)phospholane (9b). Prepared in a similar manner to phospholane 9c. ${ }^{31} \mathrm{P}$ NMR $\left(162 \mathrm{MHz}, \mathrm{CDCl}_{3}\right) \delta \mathrm{ppm}-10.7$ (s).

Phospholane 9b was converted to its phosphine sulfide derivative for characterization purposes via the following procedure:<smiles>COC[C@@H]1CCCP1c1ccccc1</smiles>

$9 b$

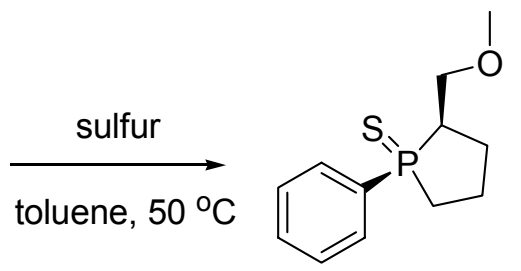

21

(1R, 2R)-1-Phenyl-2-(methoxymethyl)phospholanesulfide (21). Crude Phospholane 9b from the cyclization procedure was dissolved in toluene and then sulfur (1.25 equiv based on $\mathbf{5 b}$ ) was added in one portion. The reaction was warmed to $50{ }^{\circ} \mathrm{C}$ and stirred under nitrogen for 12 hours and then the volatiles were removed invacuo producing a clear oil. The oil was chromatographed over silica gel $(30 \%$ ethyl acetate in hexanes) producing $21(31 \%$ from $\mathbf{5 b})$ as a single diastereomer. bp $171.3{ }^{\circ} \mathrm{C} ;[\alpha]^{24}{ }_{\mathrm{D}}=+56.2^{\circ}(\mathrm{c}$ 1.0, $\left.\mathrm{CHCl}_{3}\right) ; 1 \mathrm{H} \mathrm{NMR}\left(400 \mathrm{MHz}, \mathrm{CDCl}_{3}\right) \delta 1.60(\mathrm{~m}, 1 \mathrm{H}) 2.23(\mathrm{~m}, 4 \mathrm{H}) 2.63(\mathrm{~m}, 2 \mathrm{H}) 2.97(\mathrm{~m}, 1 \mathrm{H}) 2.97$ $(\mathrm{s}, 3 \mathrm{H}) 3.12(\mathrm{~m}, 1 \mathrm{H}) 7.48(\mathrm{~m}, 3 \mathrm{H}) 7.86(\mathrm{~m}, 2 \mathrm{H}) ; 13 \mathrm{C} \mathrm{NMR}\left(101 \mathrm{MHz}, \mathrm{CDCl}_{3}\right) \delta \mathrm{ppm} 24.32(\mathrm{~d}, J=4.61$ $\mathrm{Hz}), 30.99$ (d, $J=9.21 \mathrm{~Hz}), 34.16(\mathrm{~d}, J=54.51 \mathrm{~Hz}), 50.00(\mathrm{~d}, J=52.21 \mathrm{~Hz}), 58.66,71.25(\mathrm{~d}, J=3.07 \mathrm{~Hz})$, 128.52 (d, $J=11.52 \mathrm{~Hz}), 128.88$ (d, $J=11.52 \mathrm{~Hz}), 130.27$ (d, $J=67.56 \mathrm{~Hz}), 131.82(\mathrm{~d}, J=9.98 \mathrm{~Hz}) ;{ }^{31} \mathrm{P}$ NMR $\left(162 \mathrm{MHz}, \mathrm{CDCl}_{3}\right) \delta$ ppm 60.72 (s). Anal. Calcd for $\mathrm{C}_{12} \mathrm{H}_{20} \mathrm{BOP}: \mathrm{C}, 59.98 ; \mathrm{H}, 7.13$. Found: $\mathrm{C}, 59.95 ; \mathrm{H}$, 7.07 .

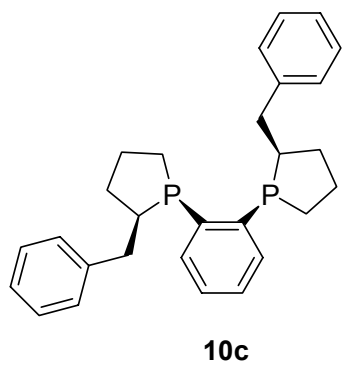

Preparation of 1,2-Bis((1R, 2R)-2-benzylphospholano)benzene (10c). To a $25 \mathrm{~mL}$ round bottom flask equipped with a magnetic stirring bar was added 1,2 -Bis(phosphino)benzene $(0.330 \mathrm{~g}, 2.33 \mathrm{mmole})$. To the flask was added $15 \mathrm{~mL}$ THF via syringe and the reaction was placed under nitrogen and cooled to $0{ }^{\circ} \mathrm{C}$. To the solution was then added $\mathrm{n}$-BuLi (1.0 equiv, $1.9 \mathrm{~mL}$ of a $2.5 \mathrm{M}$ solution in hexanes) and the reaction was stirred 1 hour at $0{ }^{\circ} \mathrm{C}$. The reaction solution was yellow indicative of phosphine anion formation. A solution of cyclic sulfate in $5 \mathrm{~mL}$ THF was then added via syringe. The reaction was stirred 30 minutes at $0{ }^{\circ} \mathrm{C}$ and then 30 minutes at room temperature. The reaction was cooled back down to $0{ }^{\circ} \mathrm{C}$ and then $\mathrm{n}$-BuLi $(2.3$ equiv, $2.1 \mathrm{~mL}$ of a $2.5 \mathrm{M}$ solution in hexanes) was added dropwise over five minutes. The reaction was stirred 30 minutes at $0{ }^{\circ} \mathrm{C}$ and then warmed to room temperature and stirred 45 minutes. The reaction was 
quenched with $1 \mathrm{~mL} \mathrm{MeOH}$ to produce a white chunky solution. The volatiles were removed invacuo and then the white oily solid was triturated with ethyl ether and then filtered to remove the sulfate salts. The solvent in the filtrate was then removed invacuo producing $780 \mathrm{mg}(78 \%)$ of 10c, a clear oil. The product could be recrystallized from hot $10: 1 \mathrm{MeOH} / \mathrm{CHCl}_{3}$ to produce the pure cis/cis diastereomer with $60 \%$ recovery. ${ }^{1} \mathrm{H}$ NMR $\left(400 \mathrm{MHz}, \mathrm{CDCl}_{3}\right) \delta 1.40(\mathrm{~m}, 2 \mathrm{H}), 1.61(\mathrm{~m}, 4 \mathrm{H}), 1.80(\mathrm{dd}, J=13.68,11.72 \mathrm{~Hz}, 2 \mathrm{H})$, 2.00 (m, $6 \mathrm{H}), 2.46$ (m, $2 \mathrm{H}), 3.00$ (dd, $J=13.68,3.66 \mathrm{~Hz}, 2 \mathrm{H}), 6.97$ (m, $4 \mathrm{H}), 7.06$ (m, $2 \mathrm{H}), 7.14$ (m, $4 \mathrm{H})$, $7.29(\mathrm{~m}, 2 \mathrm{H}), 7.37(\mathrm{~m}, 2 \mathrm{H}) ;{ }^{13} \mathrm{C}$ NMR $(101 \mathrm{MHz}, \mathrm{CDCl} 3) \delta 24.07,26.09,32.70,38.59(\mathrm{t}, J=3.84 \mathrm{~Hz})$, $42.62(\mathrm{t}, J=7.68 \mathrm{~Hz}), 128.32(\mathrm{~m}, J=5.37 \mathrm{~Hz}), 128.45,128.92,131.64(\mathrm{t}, J=1.54 \mathrm{~Hz}), 142.59(\mathrm{t}, J=3.84 \mathrm{~Hz})$, $143.99 ;{ }^{31} \mathrm{P}$ NMR $\left(162 \mathrm{MHz}, \mathrm{CDCl}_{3}\right) \delta-16.53(\mathrm{~s})$.

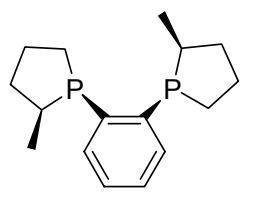

$10 \mathrm{a}$

Preparation of 1,2-Bis((1R, 2S)-2-methylphospholano)benzene (10a). Prepared in a similar manner to phospholane 10c. ${ }^{31} \mathrm{P}$ NMR $\left(162 \mathrm{MHz}, \mathrm{CDCl}_{3}\right) \delta \mathrm{ppm}-15.1$ (s).

Phospholane 10a was converted to its phosphine sulfide derivative for characterization purposes via the following procedure:

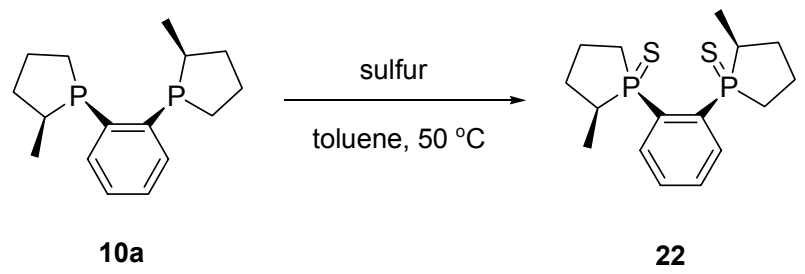

Preparation of 1,2-Bis((1R, 2S)-2-methylphospholanosulfide)benzene (22). Prepared in a similar procedure to that of $\mathbf{2 1}$ using 2.25 eq. sulfur. The resulting white solid was recrystallized from hot toluene producing $22\left(44 \%\right.$ yield from 5a) as a single diastereomer. $\mathrm{mp} 245.0-246.5^{\circ} \mathrm{C} ;[\alpha]^{24}{ }_{\mathrm{D}}=+2.3^{\circ}(\mathrm{c} 1.0$, $\left.\mathrm{CHCl}_{3}\right) ;{ }^{1} \mathrm{H} \mathrm{NMR}\left(400 \mathrm{MHz}, \mathrm{CDCl}_{3}\right) \delta 0.98(\mathrm{dd}, J=19.29,7.57 \mathrm{~Hz}, 6 \mathrm{H}), 1.76(\mathrm{~m}, 2 \mathrm{H}), 1.96(\mathrm{~m}, 2 \mathrm{H})$, $2.25(\mathrm{~m}, 4 \mathrm{H}), 2.45(\mathrm{~m}, 2 \mathrm{H}), 3.14(\mathrm{~s}, 4 \mathrm{H}), 7.50(\mathrm{~m}, 2 \mathrm{H}), 7.64(\mathrm{~m}, 2 \mathrm{H}) ;{ }^{13} \mathrm{C} \mathrm{NMR}\left(101 \mathrm{MHz}, \mathrm{CDCl}_{3}\right) \delta$ 18.47, 23.30 (t, $J=3.84 \mathrm{~Hz}), 33.16,42.60$ (d, $J=52.98 \mathrm{~Hz}), 130.50,132.99$ (t, $J=9.21 \mathrm{~Hz}), 135.93$ (dd, $J=66.03,6.91 \mathrm{~Hz}) ;{ }^{31} \mathrm{P}$ NMR $\left(162 \mathrm{MHz}, \mathrm{CDCl}_{3}\right) \delta 71.84$ (s). HRMS (EI): $(\mathrm{M}+\mathrm{H})^{+} 343.0887\left((\mathrm{M}+\mathrm{H})^{+}\right.$, exact mass calcd for $\left.\mathrm{C}_{16} \mathrm{H}_{25} \mathrm{P}_{2} \mathrm{~S}_{2}: 343.0873\right)$.

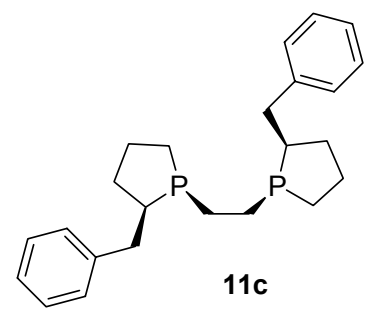

Preparation of 1,2-Bis((1S, 2R)-2-benzylphospholano)ethane (11c). Prepared in a similar procedure as that of phospholane 10c. ${ }^{31} \mathrm{P}$ NMR $\left(162 \mathrm{MHz}, \mathrm{CDCl}_{3}\right) \delta-13.3$ (s). 
Phospholane 11c was converted to its bis-borane derivative for characterization purposes via the following procedure:

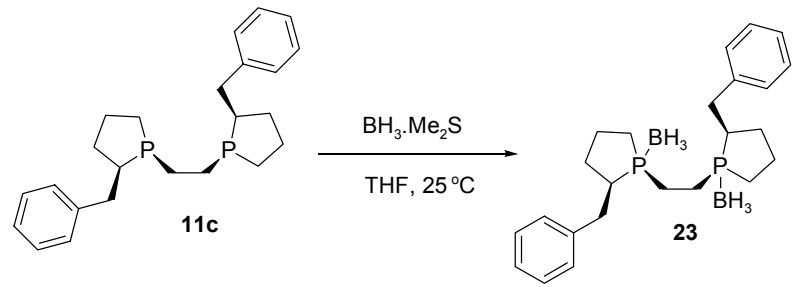

Preparation of 1,2-Bis((1S, 2R)-2-benzylphospholaneborane)ethane (23). Prepared in a similar procedure as that of compound 19 using 2 equiv $\mathrm{BH}_{3} \cdot \mathrm{Me}_{2} \mathrm{~S}$. Recrystallization of the product from isopropanol provided 23 as a single diastereomer in $35 \%$ yield. mp $178.4-179.4{ }^{\circ} \mathrm{C} ;[\alpha]^{24}{ }_{\mathrm{D}}=-25.3^{\circ}(\mathrm{c}$ 1.0, CHCl3); 1H NMR (400 MHz, $\left.\mathrm{CDCl}_{3}\right) \delta 0.69(\mathrm{~m}, 6 \mathrm{H}), 1.42(\mathrm{~m}, 2 \mathrm{H}), 1.68(\mathrm{~m}, 6 \mathrm{H}), 2.01(\mathrm{~m}, 8 \mathrm{H})$, $2.33(\mathrm{~m}, 2 \mathrm{H}), 2.52(\mathrm{~m}, 2 \mathrm{H}), 3.00(\mathrm{~m}, 2 \mathrm{H}), 7.21(\mathrm{~m}, 10 \mathrm{H}) ;{ }^{13} \mathrm{C}$ NMR $\left(101 \mathrm{MHz}, \mathrm{CDCl}_{3}\right) \delta 16.46(\mathrm{~d}$, $J=25.34 \mathrm{~Hz}$ ), 24.64, 24.96 (d, $J=34.55 \mathrm{~Hz}), 33.05,34.70,40.48$ (d, $J=33.01 \mathrm{~Hz}), 126.85,128.79,128.83$, $139.51(\mathrm{~d}, J=9.98 \mathrm{~Hz}) ;{ }^{31} \mathrm{P}$ NMR $\left(162 \mathrm{MHz}, \mathrm{CDCl}_{3}\right) \delta 36.78$ (s). Anal. Calcd for $\mathrm{C}_{24} \mathrm{H}_{38} \mathrm{~B}_{2} \mathrm{P}_{2}: \mathrm{C}, 70.29 ; \mathrm{H}$, 9.34. Found: C, 70.15; H, 9.45 .

General Procedure for Epimerization: After quenching the cyclization reaction of compounds 9-11 with $\mathrm{MeOH}$ and removing the solvent, the crude product (jelly-like) was placed under $\mathrm{N}_{2}$. The jelly was then heated in an oil bath to $190^{\circ} \mathrm{C}$ for 4 hours. After cooling to room temperature, the vacuum attachment was quickly replaced with a septum and the flask immediately placed under $\mathrm{N}_{2}$ (it is important to cool the product before exposing to air for a short time to avoid oxidation). To the flask was added $15 \mathrm{~mL}$ ethyl ether via syringe and the jelly was then vigorously triturated. The ethyl ether was then collected with a syringe equipped with a 6 inch needle and filtered through a 0.20 micron SFCA syringe filter into another round bottom under $\mathrm{N}_{2}$. White solid remained in the flask (sulfate salts). The trituration was repeated twice. The combined ether extractions were evaporated using a vacuum pump leaving an oil. ${ }^{31} \mathrm{P}$ NMR of an aliquot of the oil showed clean conversion to predominantly trans and trans/trans products in ratios described in Scheme 1.<smiles>C[C@H]1CCCP1c1ccccc1</smiles>

$13 a$

(1S, 2S)-1-Phenyl-2-methylphospholane (13a). ${ }^{31} \mathrm{P} \mathrm{NMR}\left(162 \mathrm{MHz}, \mathrm{CDCl}_{3}\right) \delta 2.2$ (s).

Phospholane 13a was converted to its borane derivative for characterization purposes via the following procedure:<smiles>C[C@H]1CCCP1c1ccccc1</smiles>

$13 a$

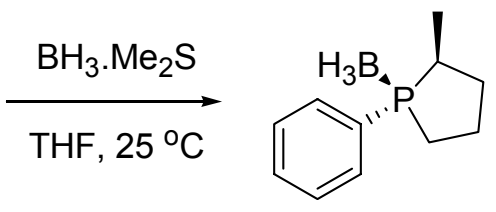

24

Preparation of (1S, 2S)-1-Phenyl-2-methylphospholaneborane (24). Prepared in a similar procedure to that of 19. The diastereomers in the isolated oil $(72 \%$ from 5a) were inseparable via column chromatography over silica gel. ${ }^{1} \mathrm{H}$ NMR $\left(400 \mathrm{MHz}, \mathrm{CDCl}_{3}\right) \delta 0.83(\mathrm{~m}, 3 \mathrm{H}), 1.27(\mathrm{dd}, J=16.36,7.08 \mathrm{~Hz}, 3$ 
H), $1.62(\mathrm{~m}, 1 \mathrm{H}), 1.86(\mathrm{~m}, 1 \mathrm{H}), 2.20(\mathrm{~m}, 5 \mathrm{H}), 7.46(\mathrm{~m}, 3 \mathrm{H}), 7.68(\mathrm{~m}, 2 \mathrm{H}) ;{ }^{13} \mathrm{C} \mathrm{NMR}\left(101 \mathrm{MHz}, \mathrm{CDCl}_{3}\right)$ $\delta 14.40(\mathrm{~d}, J=5.37 \mathrm{~Hz}), 26.18,26.94(\mathrm{~d}, J=38.39 \mathrm{~Hz}), 35.28$ (d, $J=35.32 \mathrm{~Hz}), 36.29$ (d, $J=6.91 \mathrm{~Hz}), 129.03$ $(\mathrm{d}, J=9.98 \mathrm{~Hz}), 131.48,131.73(\mathrm{~d}, J=24.57 \mathrm{~Hz}), 131.67$ (d, $J=9.21 \mathrm{~Hz}) ; \mathrm{HRMS}(\mathrm{EI}):\left(\mathrm{M}-\mathrm{BH}_{3}+\mathrm{H}\right)^{+}$ $179.1136\left(\left(\mathrm{M}-\mathrm{BH}_{3}+\mathrm{H}\right)^{+}\right.$, exact mass calcd for $\left.\mathrm{C}_{11} \mathrm{H}_{16} \mathrm{P}: 179.0990\right)$.<smiles>COC[C@H]1CCCP1c1ccccc1</smiles>

$13 b$

(1S, 2R)-1-Phenyl-2-(methoxymethyl)phospholane (13b). ${ }^{31} \mathrm{P}$ NMR (162 MHz, $\left.\mathrm{CDCl}_{3}\right) \delta-6.2$ (s).

Phospholane 13b was converted to its phosphine sulfide derivative for characterization purposes via the following procedure:<smiles>COC[C@@H]1CCCP1c1ccccc1</smiles>

$13 b$

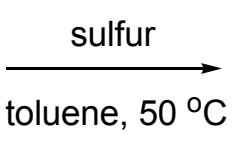

toluene, $50^{\circ} \mathrm{C}$<smiles>COC[C@H]1CCCP1(=S)c1ccccc1</smiles>

25

Preparation of (1S, 2R)-1-Phenyl-2-(methoxymethyl)phospholanesulfide (25). Prepared in a similar procedure to that of 21. Column chromatography over Si gel (30\% ethyl acetate in hexanes) provided a clear oil (31\% from $\mathbf{5 b})$ as a single diastereomer. bp $155.6{ }^{\circ} \mathrm{C} ;{ }^{1} \mathrm{H}$ NMR $\left(400 \mathrm{MHz}, \mathrm{CDCl}_{3}\right) \delta 1.84(\mathrm{~m}, 2$ H), $2.27(\mathrm{~m}, 3 \mathrm{H}), 2.47(\mathrm{~m}, 1 \mathrm{H}), 2.63(\mathrm{~m}, 1 \mathrm{H}), 3.29(\mathrm{~s}, 2 \mathrm{H}), 3.56(\mathrm{~m}, 1 \mathrm{H}), 3.75(\mathrm{~m}, 1 \mathrm{H}), 7.48(\mathrm{~m}, 3 \mathrm{H})$, $7.86(\mathrm{~m}, 2 \mathrm{H}) ;{ }^{13} \mathrm{C}$ NMR $\left(101 \mathrm{MHz}, \mathrm{CDCl}_{3}\right) \delta 25.11(\mathrm{~d}, J=3.84 \mathrm{~Hz}), 30.41(\mathrm{~d}, J=9.98 \mathrm{~Hz}), 36.84(\mathrm{~d}$, $J=55.28 \mathrm{~Hz}), 43.33$ (d, $J=52.98 \mathrm{~Hz}), 59.20,71.84(\mathrm{~d}, J=4.61 \mathrm{~Hz}), 128.88$ (d, $J=11.52 \mathrm{~Hz}), 130.59$ (d, $J=10.75 \mathrm{~Hz}), 131.69$ (d, $J=3.07 \mathrm{~Hz}), 133.95$ (d, $J=71.40 \mathrm{~Hz}) ;{ }^{31} \mathrm{P}$ NMR $\left(162 \mathrm{MHz}, \mathrm{CDCl}_{3}\right) \delta 60.69$ (s). Anal. Calcd for $\mathrm{C}_{12} \mathrm{H}_{20}$ BOP: C, 59.98; H, 7.13. Found: C, 59.321; H, 6.85.<smiles>c1ccc(C[C@@H]2CCCP2c2ccccc2)cc1</smiles>

(1S, 2R)-1-Phenyl-2-benzylphospholane (13c). ${ }^{31} \mathrm{P}$ NMR $\left(162 \mathrm{MHz}, \mathrm{CDCl}_{3}\right) \delta-2.9$ (s). 
Phospholane 13c was converted to its borane derivative for characterization purposes via the following procedure:<smiles>[B][Pb]1(c2ccccc2)CCC[C@@H]1Cc1ccccc1</smiles>

(1S, 2R)-1-Phenyl-2-benzylphospholaneborane (26). Prepared in a similar procedure to that of 19 . The diastereomers in the isolated solid were recrystallized from $15 \%$ ethyl acetate in hexanes to provide a single diastereomer in $61 \%$ yield. ${ }^{1} \mathrm{H}$ NMR $\left(400 \mathrm{MHz}, \mathrm{CDCl}_{3}\right) \delta 1.02(\mathrm{~m}, 3 \mathrm{H}), 1.65(\mathrm{~m}, 1 \mathrm{H}), 1.80(\mathrm{~m}, 1 \mathrm{H}), 2.14$ $(\mathrm{m}, 4 \mathrm{H}), 2.47(\mathrm{~m}, 1 \mathrm{H}), 2.81(\mathrm{~m}, 1 \mathrm{H}), 3.12(\mathrm{~m}, 1 \mathrm{H}), 7.16(\mathrm{~m}, 5 \mathrm{H}), 7.44(\mathrm{~m}, 3 \mathrm{H}), 7.64(\mathrm{~m}, 2 \mathrm{H}) ;{ }^{13} \mathrm{C}$ NMR $\left(101 \mathrm{MHz}, \mathrm{CDCl}_{3}\right) \delta 26.00,27.02(\mathrm{~d}, J=39.16 \mathrm{~Hz}), 33.51(\mathrm{~d}, J=6.91 \mathrm{~Hz}), 35.46(\mathrm{~d}, J=6.91 \mathrm{~Hz})$, 42.96 (d, $J=33.01 \mathrm{~Hz}), 126.44,128.57,128.98,129.09,131.35(\mathrm{~d}, J=2.30 \mathrm{~Hz}), 140.62(\mathrm{~d}, J=12.28 \mathrm{~Hz}) ;{ }^{31} \mathrm{P}$ $\operatorname{NMR}\left(162 \mathrm{MHz}, \mathrm{CDCl}_{3}\right) \delta 34.02(\mathrm{~s})$.

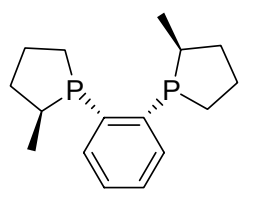

2a

Preparation of 1,2-Bis((1S, 2S)-2-methylphospholano)benzene (2a). ${ }^{31} \mathrm{P}$ NMR (162 MHz, $\left.\mathrm{CDCl}_{3}\right) \delta-6.2$ (s).

Phospholane 2a was converted to its phosphine sulfide derivative for characterization purposes via the following procedure:

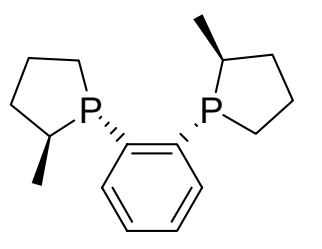

$2 a$

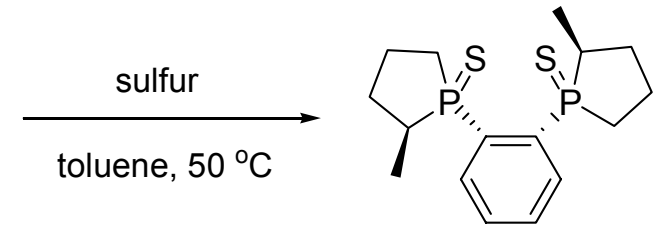

27

1,2-Bis((1S, 2S)-2-methylphospholanesulfide)benzene (27). Prepared in a similar procedure to that of 21 using 2.25 equiv sulfur. The resulting white solid was recrystallized from $70 \%$ ethyl acetate in hexanes to provide 27 as a single diastereomer in $21 \%$ yield (from 5a). mp $188.4-192.7^{\circ} \mathrm{C} ;[\alpha]^{20}{ }_{\mathrm{D}}=-179.2^{\circ}$ (c 1.0, $\left.\mathrm{CHCl}_{3}\right) ;{ }^{1} \mathrm{H}$ NMR $\left(400 \mathrm{MHz}, \mathrm{CDCl}_{3}\right) \delta 1.54(\mathrm{dd}, J=17.95,6.72 \mathrm{~Hz}, 6 \mathrm{H}), 1.65(\mathrm{~m}, 4 \mathrm{H}), 2.14(\mathrm{~m}, 4 \mathrm{H})$, $2.29(\mathrm{~m}, 2 \mathrm{H}), 2.58(\mathrm{~m}, 2 \mathrm{H}), 4.45(\mathrm{~m}, 2 \mathrm{H}), 7.48(\mathrm{~m}, J=1.71 \mathrm{~Hz}, 2 \mathrm{H}), 7.64(\mathrm{~m}, 2 \mathrm{H}) ;{ }^{13} \mathrm{C}$ NMR $(101 \mathrm{MHz}$, $\left.\mathrm{CDCl}_{3}\right) \delta 15.39,24.30,34.08,37.11$ (d, $\left.J=50.67 \mathrm{~Hz}\right), 38.88$ (d, $\left.J=54.51 \mathrm{~Hz}\right), 131.21$ (dt, $J=8.64,4.61,4.41$ $\mathrm{Hz}), 132.72$ (dd, $J=10.37 \mathrm{~Hz}), 139.60$ (dd, $J=66.41,8.06 \mathrm{~Hz}) ;{ }^{31} \mathrm{P}$ NMR $\left(162 \mathrm{MHz}, \mathrm{CDCl}_{3}\right) \delta 67.39$ (s). HRMS (EI): $(\mathrm{M}+\mathrm{H})^{+} 343.0866\left((\mathrm{M}+\mathrm{H})^{+}\right.$, exact mass calcd for $\left.\mathrm{C}_{16} \mathrm{H}_{25} \mathrm{P}_{2} \mathrm{~S}_{2}: 343.0873\right)$. 


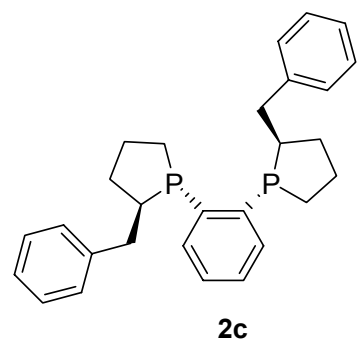

Preparation of 1,2-Bis((1S, 2R)-2-benzylphospholano)benzene (2c). ${ }^{31} \mathrm{P}$ NMR $\left(162 \mathrm{MHz}, \mathrm{CDCl}_{3}\right) \delta-8.1$ (s).

Phospholane 2c was converted to its bis-borane derivative for characterization purposes via the following procedure:

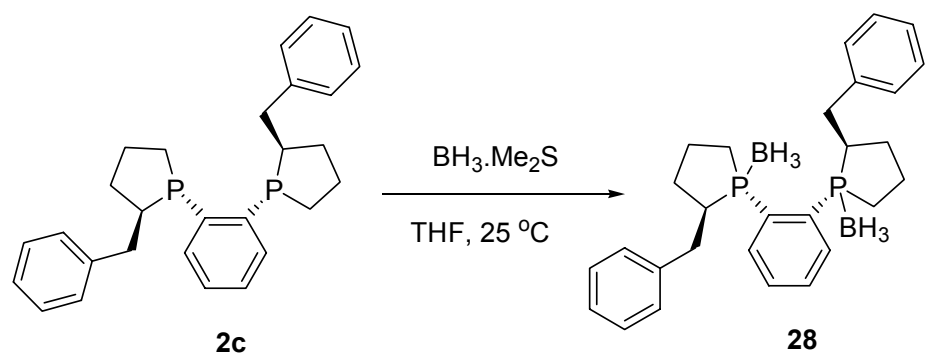

Preparation of 1,2-Bis((1S, 2R)-2-benzylphospholanoborane)benzene (28). Prepared in a similar procedure to that of 19 using 2 equiv $\mathrm{BH}_{3} \cdot \mathrm{Me}_{2} \mathrm{~S}$. White crystals formed in the THF solution and were collected in $44 \%$ yield (from 5c) as a single diastereomer. mp $189.8-195.0{ }^{\circ} \mathrm{C} ;[\alpha]^{20}{ }_{\mathrm{D}}=-99.4^{\circ}(\mathrm{c} 1.1$, $\left.\mathrm{CHCl}_{3}\right) ;{ }^{1} \mathrm{H} \mathrm{NMR}\left(400 \mathrm{MHz}, \mathrm{CDCl}_{3}\right) \delta 1.02(\mathrm{~m}, 6 \mathrm{H}), 1.54(\mathrm{~m}, 2 \mathrm{H}), 1.70(\mathrm{~m}, 2 \mathrm{H}), 1.94(\mathrm{~s}, 2 \mathrm{H}), 2.12(\mathrm{~m}$, $4 \mathrm{H}), 2.70(\mathrm{~s}, 2 \mathrm{H}), 2.92(\mathrm{~s}, 2 \mathrm{H}), 3.35(\mathrm{~m}, 2 \mathrm{H}), 3.52(\mathrm{~s}, 2 \mathrm{H}), 7.27(\mathrm{~s}, 10 \mathrm{H}), 7.49(\mathrm{~s}, 2 \mathrm{H}), 7.63$ (s, $2 \mathrm{H})$; ${ }^{13} \mathrm{C}$ NMR $\left(101 \mathrm{MHz}, \mathrm{CDCl}_{3}\right) \delta 25.72,27.80(\mathrm{~d}, J=33.78 \mathrm{~Hz}), 32.94(\mathrm{~d}, J=7.68 \mathrm{~Hz}), 37.06(\mathrm{~d}, J=5.37 \mathrm{~Hz})$, $44.80(\mathrm{~d}, J=33.78 \mathrm{~Hz}), 126.79,128.95$ (d, $J=9.98 \mathrm{~Hz}), 130.37(\mathrm{~d}, J=6.91 \mathrm{~Hz}), 133.19,136.85(\mathrm{~d}, J=6.14$ $\mathrm{Hz}), 137.24$ (d, $J=5.38 \mathrm{~Hz}), 140.43(\mathrm{~d}, J=13.82 \mathrm{~Hz}) ;{ }^{31} \mathrm{P} \mathrm{NMR}\left(162 \mathrm{MHz}, \mathrm{CDCl}_{3}\right) \delta 42.74$ (s). Anal. Calcd for $\mathrm{C}_{28} \mathrm{H}_{38} \mathrm{~B}_{2} \mathrm{P}_{2}$ : C, 73.40; H, 8.36. Found: C, 73.36; H, 8.61.

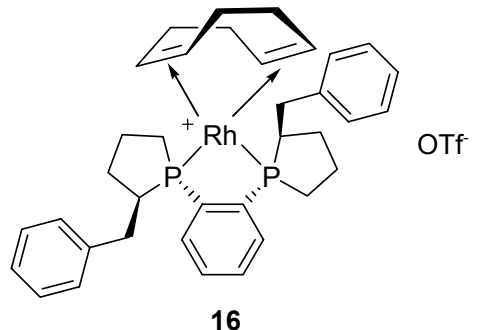

Synthesis of $[\mathbf{R h}(\mathbf{2 c})(\mathbf{C O D})]^{+} \mathbf{O T f}^{-16)}$. Phospholane $\mathbf{2 c}(200 \mathrm{mg}, 0.465 \mathrm{mmole})$ was dissolved in $5 \mathrm{~mL}$ THF and delivered to a solution of $\left[\mathrm{Rh}(\mathrm{COD})_{2}\right]^{+} \mathrm{OTf}^{-}(211 \mathrm{mg}, 0.451 \mathrm{mmole})$ in $5 \mathrm{~mL} \mathrm{MeOH}$ dropwise with stirring. The metal solution turned from dark red to orange. The reaction was stirred for 45 minutes and then the volatiles were removed invacuo. The remaining orange paste was washed with ether and hexane producing an orange crusty solid. The product was dissolved in minimal THF. Addition of a small amount of hexane immediately produced small red crystals. The recrystallization was let stand for two hours and then the solvent was removed with a pipette. The orange crystals were washed three times with hexane and then the crystals were dried invacuo producing $224 \mathrm{mg}(61 \%)$ of crystalline product. 
${ }^{1} \mathrm{H}$ NMR (400 MHz, $\left.\mathrm{CDCl}_{3}\right) \delta 1.56(\mathrm{~m}, 2 \mathrm{H}), 1.85(\mathrm{~m}, 4 \mathrm{H}), 2.05(\mathrm{~m}, 2 \mathrm{H}), 2.32(\mathrm{~m}, 4 \mathrm{H}) ,2.54(\mathrm{~m}, 8 \mathrm{H})$, $2.87(\mathrm{~m}, 4 \mathrm{H}), 3.14(\mathrm{~m}, 2 \mathrm{H}), 5.31(\mathrm{~d}, J=102.33 \mathrm{~Hz}), 6.73(\mathrm{~d}, J=7.08 \mathrm{~Hz}), 6.97(\mathrm{~m}, 6 \mathrm{H}), 7.44(\mathrm{~m}, 2 \mathrm{H})$, $7.57(\mathrm{~m}, 2 \mathrm{H}) ;{ }^{13} \mathrm{C}$ NMR $\left(101 \mathrm{MHz}, \mathrm{CDCl}_{3}\right) \delta 14.06,14.40$ (d, $\left.J=5.37 \mathrm{~Hz}\right), 25.09$ (d, $\left.J=36.08 \mathrm{~Hz}\right), 26.18$, $26.94(\mathrm{~d}, J=38.39 \mathrm{~Hz}), 35.08$ (d, $J=36.08 \mathrm{~Hz}), 35.27$ (d, $J=35.32 \mathrm{~Hz}), 36.11,36.29$ (d, $J=6.91 \mathrm{~Hz}), 128.79$ (d, $J=9.21 \mathrm{~Hz}), 129.04$ (d, $J=9.98 \mathrm{~Hz}), 131.27$ (d, $J=2.30 \mathrm{~Hz}), 131.61$ (d, $J=46.07 \mathrm{~Hz}), 131.49$ (d, $J=2.30$ $\mathrm{Hz}), 131.67$ (d, $J=9.21 \mathrm{~Hz}), 133.09$ (d, $J=8.44 \mathrm{~Hz}) ;{ }^{31} \mathrm{P}$ NMR $\left(162 \mathrm{MHz}, \mathrm{CDCl}_{3}\right) \delta 63.05$ (d, J=148.33 Hz).

Assignment of relative and absolute stereochemistry of phospholanes. All cis and cis/cis products were assigned by analogy to the relative and absolute stereochemistry of $\mathbf{1 9}$ and 22 as proven by x-ray crystallography. Trans and trans/trans products were assigned by analogy to the relative and absolute stereochemistry of $\mathbf{1 6}$ as proven by x-ray crystallography. The x-ray crystallographic data for $\mathbf{1 6}$ will be reported under separate cover.

Determination of Isomeric Ratios of Phospholanes from Cyclization and Epimerization. Cis:trans ratios of compounds 9a-c and 13a-c were measured via integration of their respective ${ }^{31} \mathrm{P}$ NMR signals. Cis/cis:cis/trans ratios were measured via integration of ${ }^{31} \mathrm{P}$ NMR signals of either free phosphines after cyclization reactions to form 10a, 10c, and 11 c or on phosphine sulfide or phosphine borane derivatives. Cis/trans:trans/trans ratios were measured via integration of ${ }^{31} \mathrm{P}$ NMR signals of either free phosphines after epimerization reactions to form $\mathbf{1 c}, \mathbf{2 a}$, and $\mathbf{2 c}$ or on phosphine sulfide or phosphine borane derivatives. While cis/cis and trans/trans products of the cyclization and epimerization were isolated and characterized, the cis/trans derivatives were not. However, the cis/trans derivatives were easily identified in ${ }^{31} \mathrm{P}$ NMR spectra by observing two ${ }^{31} \mathrm{P}$ NMR signals with equal coupling constants. Representative examples of ${ }^{31} \mathrm{P}$ NMR spectra showing integration ratios are depicted in Figures 1S $-4 \mathrm{~S}$ below:

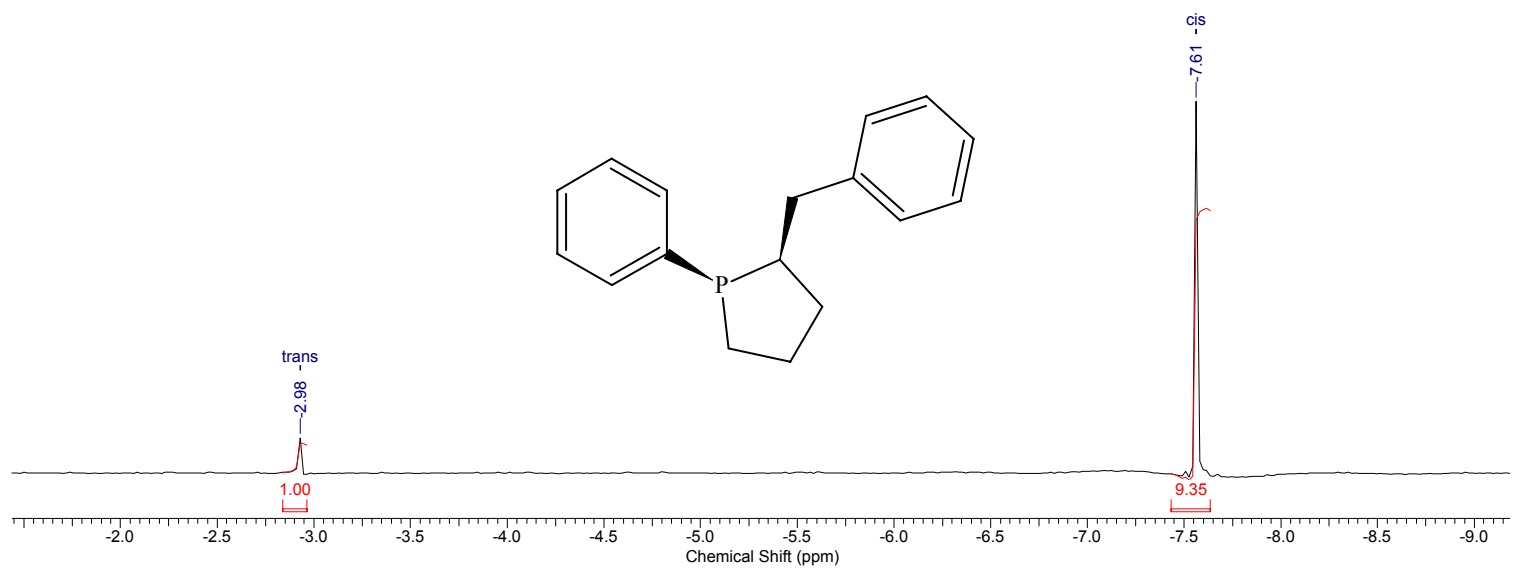

Figure 1S. ${ }^{31} \mathrm{P}$ NMR spectrum depicting the cis/trans ratio of product $9 \mathrm{c}$. 


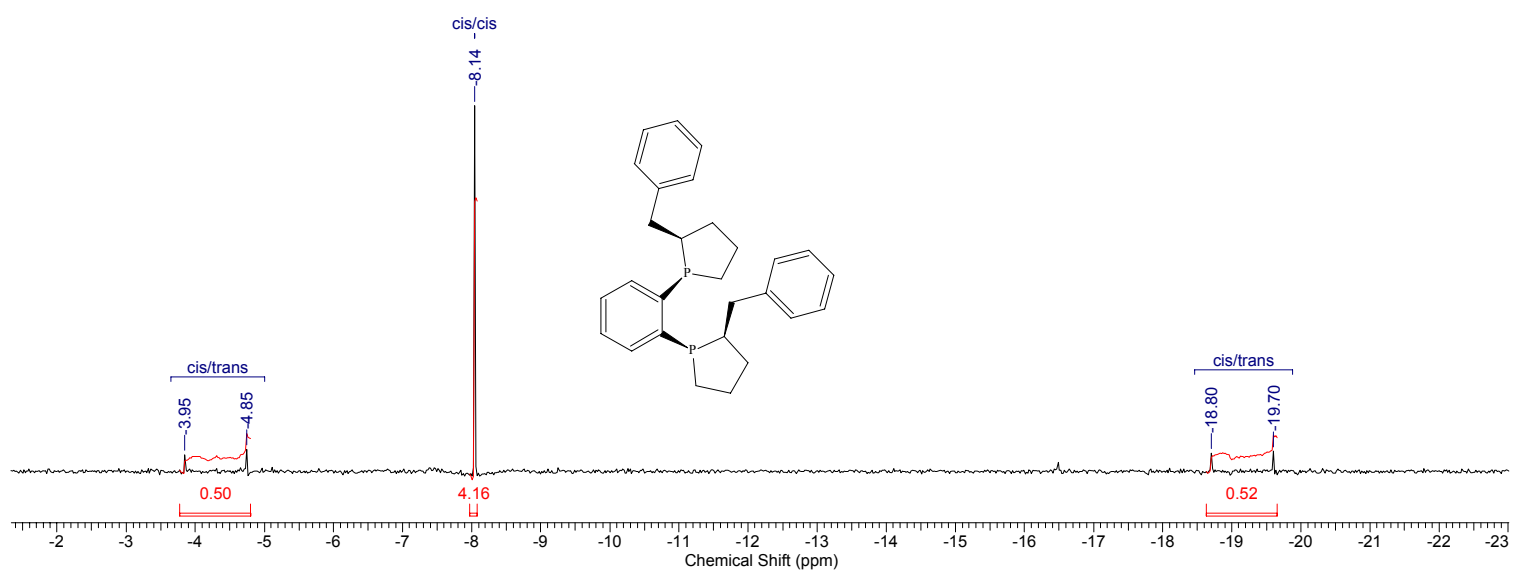

Figure 2S. ${ }^{31} \mathrm{P}$ NMR spectrum depicting the cis/cis:trans/trans ratio of product 10c.

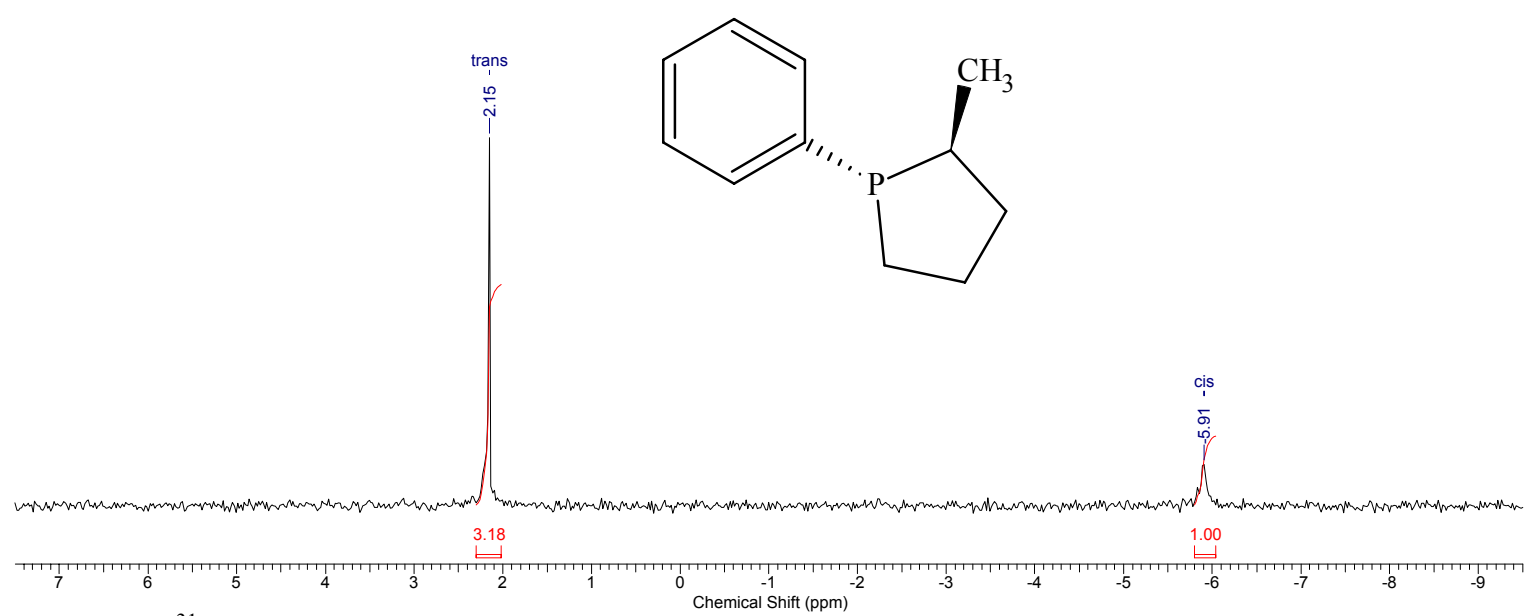

Figure 3S. ${ }^{31} \mathrm{P}$ NMR spectrum depicting the cis/trans ratio of product 13a.

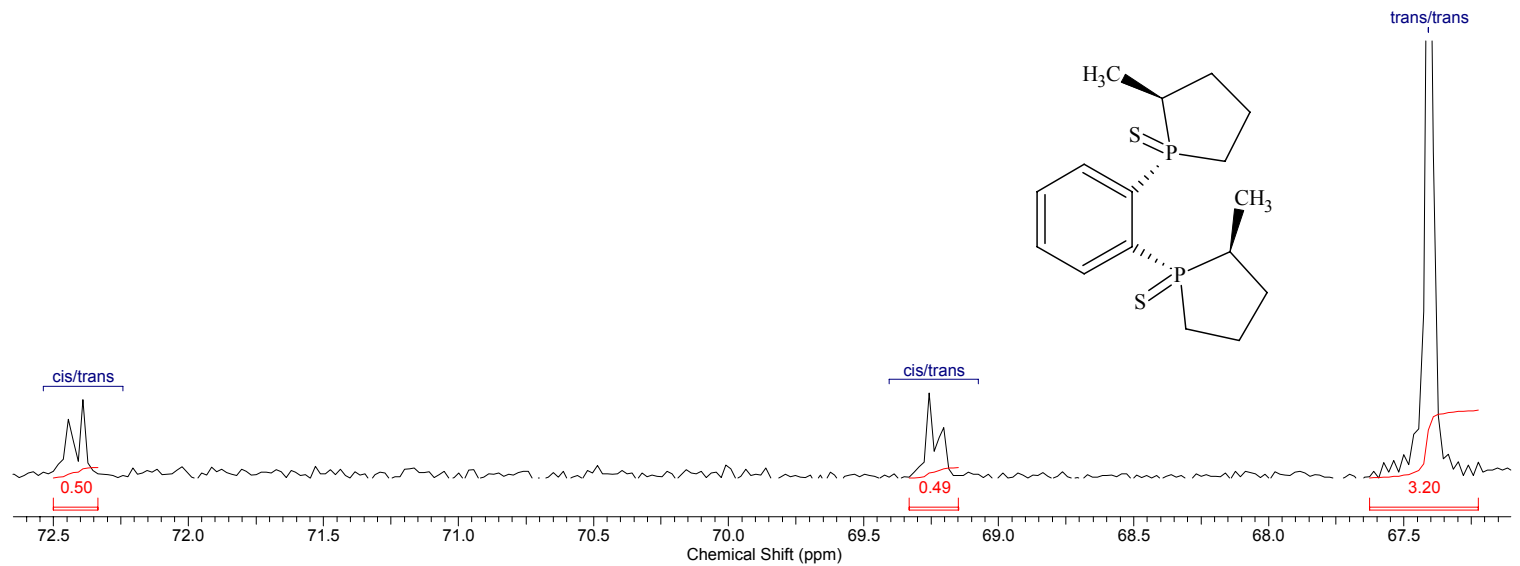

Figure 4S. ${ }^{31} \mathrm{P}$ NMR spectrum depicting the cis/trans:trans/trans ratio of the sulfide adduct of $\mathbf{2 a}$. 


\section{X-RAY CRYSTALLOGRAPHY REPORT}
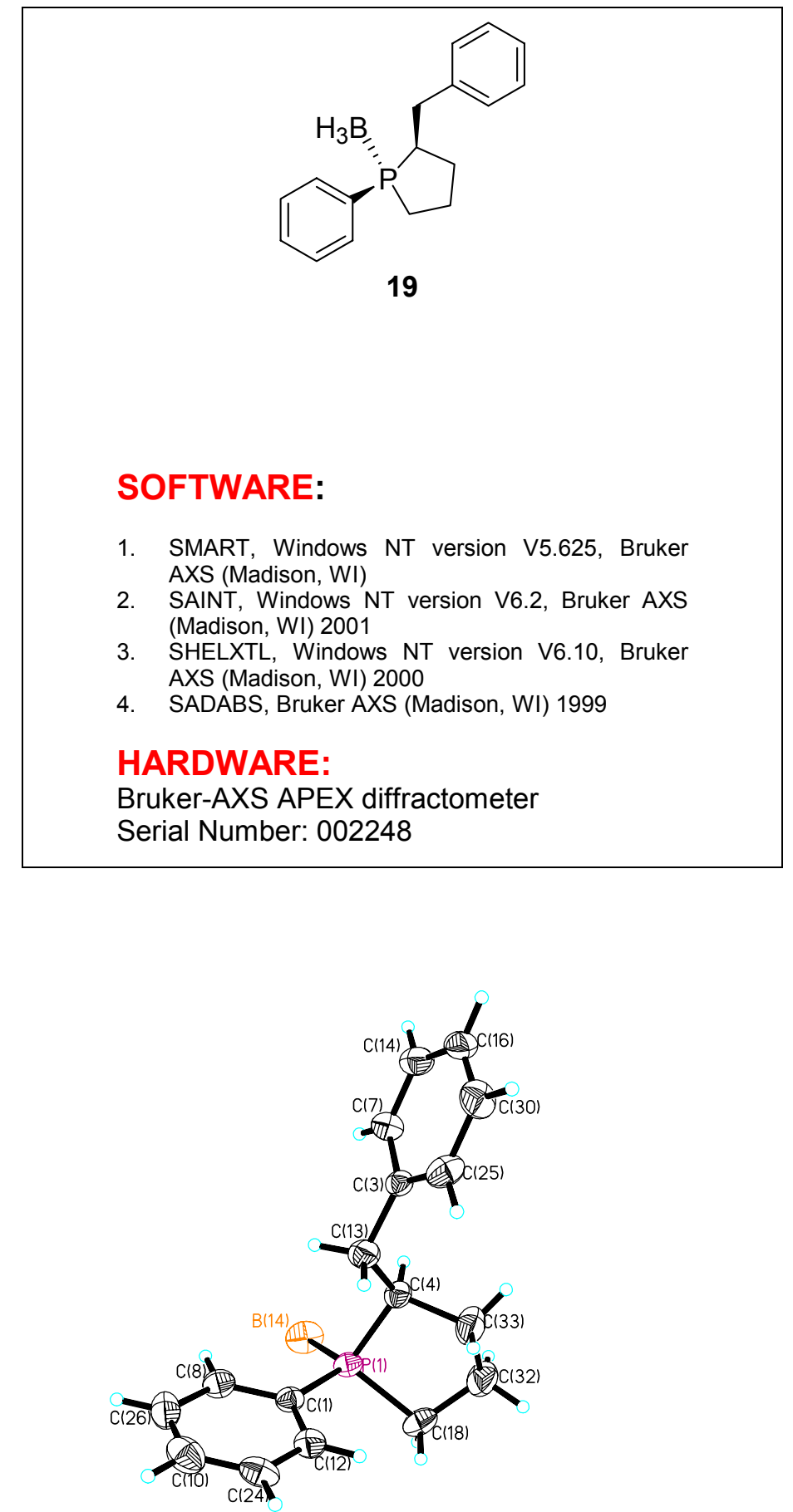

Figure 5S. ORTEP drawing of $\mathbf{1 9}$ (one of two molecules in the asymmetric unit). 
Table 1S. Crystal data and structure refinement for compound 19.

Crystallization

Empirical formula

Formula weight

Temperature

Wavelength

Crystal system

Space group

Unit cell dimensions

Volume

Z

Density (calculated)

Absorption coefficient

$\mathrm{F}(000)$

Crystal size

Theta range for data collection

Index ranges

Reflections collected

Independent reflections

Completeness to theta $=28.24^{\circ}$

Absorption correction

Max. and min. transmission

Refinement method

Data / restraints / parameters

Goodness-of-fit on $\mathrm{F}^{2}$

Final R indices [I $>2 \operatorname{sigma}(\mathrm{I})]$

$\mathrm{R}$ indices (all data)

Absolute structure parameter

Largest diff. peak and hole
EtOAc slow evaporation

C17 H19 B P

265.10

299(2) K

$0.71073 \AA$

Triclinic

P1

$\begin{array}{ll}\mathrm{a}=9.6803(17) \AA & \alpha=61.938(3)^{\circ} . \\ \mathrm{b}=10.1882(18) \AA & \beta=76.230(3)^{\circ} . \\ \mathrm{c}=10.5467(18) \AA & \gamma=63.747(3)^{\circ} .\end{array}$

$822.6(2) \AA^{3}$

2

$1.070 \mathrm{Mg} / \mathrm{m}^{3}$

$0.152 \mathrm{~mm}^{-1}$

282

$0.29 \times 0.08 \times 0.08 \mathrm{~mm}^{3}$

2.19 to $28.24^{\circ}$.

$-12<=\mathrm{h}<=12,-13<=\mathrm{k}<=13,-13<=1<=13$

7249

$6399[\mathrm{R}(\mathrm{int})=0.0181]$

$91.0 \%$

SADABS

0.9880 and 0.9573

Full-matrix least-squares on $\mathrm{F}^{2}$

$6399 / 3 / 343$

1.021

$\mathrm{R} 1=0.0761, \mathrm{wR} 2=0.1454$

$\mathrm{R} 1=0.1472, \mathrm{wR} 2=0.1765$

$0.03(14)$

0.241 and -0.166 e. $\AA^{-3}$ 
Table 2S. Atomic coordinates $\left(\times 10^{4}\right)$ and equivalent isotropic displacement parameters $\left(\AA^{2} \times 10^{3}\right)$ for compound 19. U(eq) is defined as one third of the trace of the orthogonalized $\mathrm{Uij}^{\mathrm{ij}}$ tensor.

\begin{tabular}{|c|c|c|c|c|}
\hline & $\mathrm{x}$ & $\mathrm{y}$ & z & $\mathrm{U}(\mathrm{eq})$ \\
\hline $\mathrm{P}(1)$ & $8862(2)$ & $5404(2)$ & $5263(1)$ & $67(1)$ \\
\hline $\mathrm{P}(2)$ & $6417(2)$ & $2872(2)$ & $2386(1)$ & $70(1)$ \\
\hline $\mathrm{C}(1)$ & $6806(7)$ & 5999(7) & $5510(6)$ & $64(2)$ \\
\hline$C(2)$ & $8454(7)$ & $2217(8)$ & $2027(6)$ & $70(2)$ \\
\hline$C(3)$ & $9628(6)$ & $548(6)$ & 7944(5) & $61(1)$ \\
\hline$C(4)$ & $9742(6)$ & $3218(7)$ & $5972(6)$ & $68(2)$ \\
\hline$C(5)$ & $5758(6)$ & $1239(7)$ & $-300(6)$ & $69(1)$ \\
\hline$C(6)$ & $5692(6)$ & 1901(7) & 1793(6) & $64(2)$ \\
\hline$C(7)$ & $10646(6)$ & $-46(7)$ & 8991(6) & $80(2)$ \\
\hline$C(8)$ & 6053(7) & $6523(7)$ & $6577(6)$ & $81(2)$ \\
\hline C(9) & $4745(7)$ & 2496(8) & $-1352(7)$ & $86(2)$ \\
\hline$C(10)$ & $3641(10)$ & $6908(9)$ & 6001(10) & $108(3)$ \\
\hline $\mathrm{C}(11)$ & $4002(7)$ & $2235(10)$ & $-2099(7)$ & $93(2)$ \\
\hline$C(12)$ & $5902(7)$ & $5951(7)$ & $4720(6)$ & $82(2)$ \\
\hline$C(13)$ & 8791(6) & 2333(7) & $7149(6)$ & $84(2)$ \\
\hline $\mathrm{B}(14)$ & 9735(11) & $6236(11)$ & $6084(10)$ & $107(3)$ \\
\hline$C(14)$ & $11397(7)$ & $-1645(9)$ & $9751(7)$ & $90(2)$ \\
\hline$B(16)$ & $5307(12)$ & $5167(9)$ & $1604(10)$ & 104(3) \\
\hline$C(15)$ & $9055(8)$ & $3286(8)$ & 894(6) & $87(2)$ \\
\hline$C(16)$ & 11158(9) & $-2719(8)$ & $9518(8)$ & $90(2)$ \\
\hline$C(17)$ & $10597(10)$ & $2827(12)$ & $560(8)$ & $112(2)$ \\
\hline$C(18)$ & 9388(9) & $5746(9)$ & $3381(6)$ & $100(2)$ \\
\hline$C(19)$ & $4213(11)$ & $742(14)$ & $-1839(9)$ & $109(3)$ \\
\hline$C(20)$ & $6053(8)$ & $1806(8)$ & 4294(6) & $90(2)$ \\
\hline$C(21)$ & $9503(8)$ & $718(8)$ & $2772(6)$ & $87(2)$ \\
\hline$C(22)$ & $5967(8)$ & $-292(9)$ & $-22(8)$ & $95(2)$ \\
\hline $\mathrm{C}(23)$ & $6554(7)$ & 1596(9) & $481(6)$ & $96(2)$ \\
\hline$C(24)$ & $4333(8)$ & $6383(8)$ & $4968(8)$ & $94(2)$ \\
\hline$C(25)$ & $9414(8)$ & $-548(9)$ & 7698(7) & $94(2)$ \\
\hline$C(26)$ & $4447(9)$ & 6989(8) & $6825(8)$ & $97(2)$ \\
\hline $\mathrm{C}(27)$ & $5109(9)$ & $902(8)$ & $4386(6)$ & $107(2)$ \\
\hline$C(28)$ & $11080(9)$ & $262(9)$ & 2444(9) & $110(2)$ \\
\hline$C(29)$ & 5633(8) & $404(7)$ & $3128(7)$ & $99(2)$ \\
\hline$C(30)$ & $10177(9)$ & $-2207(9)$ & $8498(9)$ & $105(2)$ \\
\hline $\mathrm{C}(31)$ & 11600(9) & 1355(13) & $1324(10)$ & $105(3)$ \\
\hline$C(32)$ & $10618(10)$ & $4180(9)$ & $3418(7)$ & $120(3)$ \\
\hline$C(33)$ & $10155(9)$ & $2840(9)$ & $4648(7)$ & $115(2)$ \\
\hline$C(34)$ & $5212(11)$ & $-541(11)$ & $-794(9)$ & $109(2)$ \\
\hline
\end{tabular}


Table 3S. Bond lengths $[\AA]$ and angles $\left[{ }^{\circ}\right]$ for compound 19.

\begin{tabular}{|c|c|c|c|}
\hline $\mathrm{P}(1)-\mathrm{C}(1)$ & $1.797(6)$ & $C(6)-P(2)-C(20)$ & $96.1(3)$ \\
\hline $\mathrm{P}(1)-\mathrm{C}(4)$ & $1.817(6)$ & $\mathrm{C}(2)-\mathrm{P}(2)-\mathrm{B}(16)$ & $115.1(4)$ \\
\hline $\mathrm{P}(1)-\mathrm{C}(18)$ & $1.829(6)$ & $\mathrm{C}(6)-\mathrm{P}(2)-\mathrm{B}(16)$ & $112.1(3)$ \\
\hline $\mathrm{P}(1)-\mathrm{B}(14)$ & $1.964(8)$ & C(20)-P(2)-B(16) & 115.1(4) \\
\hline $\mathrm{P}(2)-\mathrm{C}(2)$ & $1.788(7)$ & $C(12)-C(1)-C(8)$ & $116.3(6)$ \\
\hline $\mathrm{P}(2)-\mathrm{C}(6)$ & $1.807(6)$ & $\mathrm{C}(12)-\mathrm{C}(1)-\mathrm{P}(1)$ & $124.5(5)$ \\
\hline$P(2)-C(20)$ & $1.817(6)$ & C(8)-C(1)-P(1) & $119.2(5)$ \\
\hline $\mathrm{P}(2)-\mathrm{B}(16)$ & $1.920(8)$ & $\mathrm{C}(21)-\mathrm{C}(2)-\mathrm{C}(15)$ & $115.9(6)$ \\
\hline$C(1)-C(12)$ & $1.373(8)$ & $\mathrm{C}(21)-\mathrm{C}(2)-\mathrm{P}(2)$ & $124.9(5)$ \\
\hline C(1)-C(8) & $1.382(8)$ & $\mathrm{C}(15)-\mathrm{C}(2)-\mathrm{P}(2)$ & $119.2(5)$ \\
\hline$C(2)-C(21)$ & $1.363(8)$ & $\mathrm{C}(25)-\mathrm{C}(3)-\mathrm{C}(7)$ & $117.3(6)$ \\
\hline$C(2)-C(15)$ & $1.399(8)$ & $C(25)-C(3)-C(13)$ & $122.5(5)$ \\
\hline$C(3)-C(25)$ & $1.364(8)$ & $C(7)-C(3)-C(13)$ & $120.1(5)$ \\
\hline$C(3)-C(7)$ & $1.385(7)$ & C(13)-C(4)-C(33) & $114.2(5)$ \\
\hline$C(3)-C(13)$ & $1.501(7)$ & C(13)-C(4)-P(1) & $115.3(4)$ \\
\hline$C(4)-C(13)$ & $1.530(7)$ & $\mathrm{C}(33)-\mathrm{C}(4)-\mathrm{P}(1)$ & $105.2(4)$ \\
\hline $\mathrm{C}(4)-\mathrm{C}(33)$ & $1.537(8)$ & $\mathrm{C}(22)-\mathrm{C}(5)-\mathrm{C}(9)$ & 117.1(6) \\
\hline$C(5)-C(22)$ & $1.371(9)$ & $C(22)-C(5)-C(23)$ & $123.5(6)$ \\
\hline$C(5)-C(9)$ & $1.380(7)$ & $\mathrm{C}(9)-\mathrm{C}(5)-\mathrm{C}(23)$ & $119.5(6)$ \\
\hline$C(5)-C(23)$ & $1.495(7)$ & $C(29)-C(6)-C(23)$ & $115.2(5)$ \\
\hline C(6)-C(29) & $1.526(8)$ & C(29)-C(6)-P(2) & $105.4(4)$ \\
\hline$C(6)-C(23)$ & $1.527(8)$ & $\mathrm{C}(23)-\mathrm{C}(6)-\mathrm{P}(2)$ & $114.8(4)$ \\
\hline$C(7)-C(14)$ & $1.351(8)$ & $\mathrm{C}(14)-\mathrm{C}(7)-\mathrm{C}(3)$ & $121.9(6)$ \\
\hline $\mathrm{C}(8)-\mathrm{C}(26)$ & $1.407(9)$ & $C(1)-C(8)-C(26)$ & $121.5(6)$ \\
\hline C(9)-C(11) & $1.359(8)$ & $\mathrm{C}(11)-\mathrm{C}(9)-\mathrm{C}(5)$ & $121.7(6)$ \\
\hline $\mathrm{C}(10)-\mathrm{C}(24)$ & $1.344(10)$ & $C(24)-C(10)-C(26)$ & $121.7(8)$ \\
\hline$C(10)-C(26)$ & $1.349(10)$ & $\mathrm{C}(19)-\mathrm{C}(11)-\mathrm{C}(9)$ & $121.4(7)$ \\
\hline C(11)-C(19) & $1.338(10)$ & $\mathrm{C}(1)-\mathrm{C}(12)-\mathrm{C}(24)$ & $122.6(6)$ \\
\hline$C(12)-C(24)$ & $1.378(8)$ & C(3)-C(13)-C(4) & $115.6(4)$ \\
\hline$C(14)-C(16)$ & $1.348(9)$ & $C(16)-C(14)-C(7)$ & $120.4(6)$ \\
\hline$C(15)-C(17)$ & $1.363(9)$ & $\mathrm{C}(17)-\mathrm{C}(15)-\mathrm{C}(2)$ & $121.2(7)$ \\
\hline $\mathrm{C}(16)-\mathrm{C}(30)$ & $1.361(10)$ & $\mathrm{C}(14)-\mathrm{C}(16)-\mathrm{C}(30)$ & $120.4(7)$ \\
\hline C(17)-C(31) & $1.337(11)$ & $\mathrm{C}(31)-\mathrm{C}(17)-\mathrm{C}(15)$ & $121.5(7)$ \\
\hline C(18)-C(32) & $1.499(10)$ & $\mathrm{C}(32)-\mathrm{C}(18)-\mathrm{P}(1)$ & $105.6(5)$ \\
\hline$C(19)-C(34)$ & $1.375(12)$ & $\mathrm{C}(11)-\mathrm{C}(19)-\mathrm{C}(34)$ & $118.5(8)$ \\
\hline$C(20)-C(27)$ & $1.521(9)$ & $\mathrm{C}(27)-\mathrm{C}(20)-\mathrm{P}(2)$ & $105.4(4)$ \\
\hline$C(21)-C(28)$ & $1.393(9)$ & $C(2)-C(21)-C(28)$ & $122.7(6)$ \\
\hline$C(22)-C(34)$ & $1.380(10)$ & $\mathrm{C}(5)-\mathrm{C}(22)-\mathrm{C}(34)$ & $120.6(7)$ \\
\hline$C(25)-C(30)$ & $1.402(9)$ & $C(5)-C(23)-C(6)$ & $116.7(4)$ \\
\hline $\mathrm{C}(27)-\mathrm{C}(29)$ & $1.536(8)$ & $\mathrm{C}(10)-\mathrm{C}(24)-\mathrm{C}(12)$ & $119.2(7)$ \\
\hline $\mathrm{C}(28)-\mathrm{C}(31)$ & $1.365(10)$ & $\mathrm{C}(3)-\mathrm{C}(25)-\mathrm{C}(30)$ & $120.9(7)$ \\
\hline \multirow[t]{2}{*}{$C(32)-C(33)$} & $1.532(9)$ & $\mathrm{C}(10)-\mathrm{C}(26)-\mathrm{C}(8)$ & $118.6(7)$ \\
\hline & & $\mathrm{C}(20)-\mathrm{C}(27)-\mathrm{C}(29)$ & $108.1(5)$ \\
\hline C(1)-P(1)-C(4) & 108.3(3) & $\mathrm{C}(31)-\mathrm{C}(28)-\mathrm{C}(21)$ & $118.7(7)$ \\
\hline $\mathrm{C}(1)-\mathrm{P}(1)-\mathrm{C}(18)$ & $108.5(3)$ & $C(6)-C(29)-C(27)$ & $106.1(5)$ \\
\hline C(4)-P(1)-C(18) & $95.3(3)$ & $\mathrm{C}(16)-\mathrm{C}(30)-\mathrm{C}(25)$ & $119.0(7)$ \\
\hline C(1)-P(1)-B(14) & $114.6(4)$ & $\mathrm{C}(17)-\mathrm{C}(31)-\mathrm{C}(28)$ & $119.9(7)$ \\
\hline C(4)-P(1)-B(14) & $111.6(3)$ & $\mathrm{C}(18)-\mathrm{C}(32)-\mathrm{C}(33)$ & 106.6(6) \\
\hline C(18)-P(1)-B(14) & $116.7(4)$ & $\mathrm{C}(32)-\mathrm{C}(33)-\mathrm{C}(4)$ & $107.2(5)$ \\
\hline $\mathrm{C}(2)-\mathrm{P}(2)-\mathrm{C}(6)$ & 108.1(3) & $\mathrm{C}(19)-\mathrm{C}(34)-\mathrm{C}(22)$ & $120.7(8)$ \\
\hline $\mathrm{C}(2)-\mathrm{P}(2)-\mathrm{C}(20)$ & $108.6(3)$ & & \\
\hline
\end{tabular}


Table 4S. Anisotropic displacement parameters $\left(\AA^{2} \times 10^{3}\right)$ for 19. The anisotropic displacement factor exponent takes the form: $-2 \pi^{2}\left[h^{2} a^{* 2} U^{11}+\ldots+2 h k a^{*} b^{*} U^{12}\right]$

\begin{tabular}{|c|c|c|c|c|c|c|}
\hline & $\mathrm{U}^{11}$ & $\mathrm{U}^{22}$ & $\mathrm{U}^{33}$ & $\mathrm{U}^{23}$ & $\mathrm{U}^{13}$ & $\mathrm{U}^{12}$ \\
\hline $\mathrm{P}(1)$ & 71(1) & $67(1)$ & $58(1)$ & $-15(1)$ & $-6(1)$ & $-33(1)$ \\
\hline $\mathrm{P}(2)$ & $84(1)$ & $70(1)$ & $51(1)$ & $-19(1)$ & $-7(1)$ & $-30(1)$ \\
\hline$C(1)$ & $76(4)$ & $56(3)$ & $60(4)$ & $-19(3)$ & $-10(3)$ & $-28(3)$ \\
\hline$C(2)$ & $82(5)$ & 73(4) & 54(4) & $-24(3)$ & $-11(3)$ & $-26(4)$ \\
\hline$C(3)$ & $58(3)$ & 65(3) & $52(3)$ & $-18(3)$ & $2(3)$ & $-27(3)$ \\
\hline C(4) & 62(4) & 77(4) & $60(4)$ & $-24(3)$ & $9(3)$ & $-31(3)$ \\
\hline $\mathrm{C}(5)$ & 61(3) & 83(4) & $65(4)$ & $-31(3)$ & $6(3)$ & $-35(3)$ \\
\hline $\mathrm{C}(6)$ & 60(4) & 78(4) & 44(3) & $-16(3)$ & $-5(3)$ & $-28(3)$ \\
\hline$C(7)$ & 78(4) & 71(4) & 84(4) & $-25(3)$ & $-13(3)$ & $-27(3)$ \\
\hline$C(8)$ & $88(5)$ & 79(4) & 73(4) & $-22(3)$ & $-5(3)$ & $-39(3)$ \\
\hline C(9) & 91(4) & $82(4)$ & $85(4)$ & $-25(4)$ & $-1(4)$ & $-47(4)$ \\
\hline $\mathrm{C}(10)$ & 91(6) & $82(5)$ & $132(8)$ & $-32(5)$ & $0(6)$ & $-33(5)$ \\
\hline $\mathrm{C}(11)$ & $88(4)$ & $108(6)$ & $72(4)$ & $-14(4)$ & $-10(3)$ & $-51(4)$ \\
\hline$C(12)$ & $80(5)$ & $82(4)$ & 79(4) & $-32(3)$ & $-13(3)$ & $-24(3)$ \\
\hline $\mathrm{C}(13)$ & $72(4)$ & 81(4) & $72(4)$ & $-17(3)$ & $7(3)$ & $-28(3)$ \\
\hline $\mathrm{B}(14)$ & $129(8)$ & $112(7)$ & $118(7)$ & $-42(6)$ & $-27(6)$ & $-73(6)$ \\
\hline $\mathrm{C}(14)$ & $82(4)$ & $88(5)$ & $78(4)$ & $-18(4)$ & $-12(3)$ & $-28(4)$ \\
\hline $\mathrm{B}(16)$ & $135(8)$ & $55(5)$ & $95(6)$ & $-19(4)$ & $-46(6)$ & $-9(5)$ \\
\hline$C(15)$ & $105(5)$ & $92(5)$ & $71(4)$ & $-21(3)$ & $-6(3)$ & $-58(4)$ \\
\hline$C(16)$ & $96(6)$ & $69(5)$ & 73(5) & $-13(4)$ & $5(4)$ & $-28(4)$ \\
\hline $\mathrm{C}(17)$ & $103(6)$ & $152(8)$ & 98(5) & $-47(6)$ & $2(5)$ & $-73(6)$ \\
\hline$C(18)$ & $122(6)$ & $109(6)$ & $54(4)$ & $-13(4)$ & $2(4)$ & $-58(5)$ \\
\hline $\mathrm{C}(19)$ & $138(8)$ & $149(8)$ & $81(6)$ & $-52(6)$ & $18(5)$ & $-95(7)$ \\
\hline $\mathrm{C}(20)$ & $113(5)$ & $99(5)$ & $50(4)$ & $-25(3)$ & $4(3)$ & $-45(4)$ \\
\hline $\mathrm{C}(21)$ & $92(5)$ & $90(5)$ & 68(4) & $-17(3)$ & $-13(3)$ & $-38(4)$ \\
\hline$C(22)$ & $101(5)$ & $78(5)$ & $92(5)$ & $-31(4)$ & $-11(4)$ & $-25(4)$ \\
\hline$C(23)$ & $82(4)$ & $154(6)$ & $86(4)$ & $-65(5)$ & $18(3)$ & $-68(4)$ \\
\hline $\mathrm{C}(24)$ & $76(5)$ & $79(4)$ & $115(6)$ & $-24(4)$ & $-34(4)$ & $-22(4)$ \\
\hline$C(25)$ & $118(6)$ & $107(6)$ & $71(4)$ & $-27(4)$ & $-11(4)$ & $-64(5)$ \\
\hline$C(26)$ & $101(6)$ & $88(5)$ & $103(6)$ & $-51(4)$ & $23(4)$ & $-38(4)$ \\
\hline $\mathrm{C}(27)$ & $141(6)$ & $106(5)$ & $56(4)$ & $-18(4)$ & $17(4)$ & $-59(5)$ \\
\hline $\mathrm{C}(28)$ & $87(6)$ & $114(6)$ & $101(6)$ & $-31(5)$ & $-33(4)$ & $-15(4)$ \\
\hline$C(29)$ & $124(5)$ & $91(5)$ & $87(5)$ & $-26(4)$ & $0(4)$ & $-61(4)$ \\
\hline $\mathrm{C}(30)$ & 137(7) & $81(5)$ & $121(6)$ & $-50(5)$ & $6(5)$ & $-58(5)$ \\
\hline $\mathrm{C}(31)$ & $71(5)$ & $164(9)$ & $97(6)$ & $-65(6)$ & $-4(5)$ & $-48(6)$ \\
\hline $\mathrm{C}(32)$ & $156(7)$ & $109(6)$ & 78(5) & $-37(4)$ & $32(4)$ & $-57(6)$ \\
\hline$C(33)$ & $160(7)$ & $107(6)$ & $90(5)$ & $-54(5)$ & $35(5)$ & $-67(5)$ \\
\hline$C(34)$ & $154(8)$ & $107(6)$ & $107(6)$ & $-56(5)$ & $20(6)$ & $-84(6)$ \\
\hline
\end{tabular}


Table 5S. Hydrogen coordinates $\left(\mathrm{x} 10^{4}\right)$ and isotropic displacement parameters $\left(\AA^{2} \mathrm{x} 10^{3}\right)$ for compound 19.

\begin{tabular}{|c|c|c|c|c|}
\hline & $\mathrm{x}$ & $\mathrm{y}$ & $\mathrm{z}$ & $\mathrm{U}(\mathrm{eq}$ \\
\hline $\mathrm{H}(4)$ & 10713 & 2873 & 6390 & 82 \\
\hline $\mathrm{H}(6)$ & 4624 & 2623 & 1522 & 77 \\
\hline $\mathrm{H}(7)$ & 10817 & 676 & 9176 & 96 \\
\hline $\mathrm{H}(8)$ & 6621 & 6568 & 7143 & 97 \\
\hline $\mathrm{H}(9)$ & 4566 & 3550 & -1555 & 103 \\
\hline $\mathrm{H}(10)$ & 2578 & 7225 & 6151 & 130 \\
\hline $\mathrm{H}(11)$ & 3333 & 3112 & -2805 & 112 \\
\hline $\mathrm{H}(12)$ & 6369 & 5613 & 3988 & 98 \\
\hline $\mathrm{H}(13 \mathrm{~A})$ & 8407 & 2804 & 7839 & 101 \\
\hline $\mathrm{H}(13 \mathrm{~B})$ & 7905 & 2520 & 6716 & 101 \\
\hline $\mathrm{H}(14)$ & 12083 & -2006 & 10439 & 108 \\
\hline $\mathrm{H}(15)$ & 8390 & 4328 & 359 & 104 \\
\hline $\mathrm{H}(16)$ & 11667 & -3817 & 10057 & 107 \\
\hline $\mathrm{H}(17)$ & 10959 & 3553 & -217 & 134 \\
\hline $\mathrm{H}(18 \mathrm{~A})$ & 8503 & 6040 & 2881 & 120 \\
\hline $\mathrm{H}(18 \mathrm{~B})$ & 9775 & 6602 & 2898 & 120 \\
\hline $\mathrm{H}(19)$ & 3696 & 575 & -2354 & 131 \\
\hline $\mathrm{H}(20 \mathrm{~A})$ & 7014 & 1061 & 4780 & 108 \\
\hline $\mathrm{H}(20 \mathrm{~B})$ & 5484 & 2558 & 4731 & 108 \\
\hline $\mathrm{H}(21)$ & 9150 & -31 & 3531 & 104 \\
\hline $\mathrm{H}(22)$ & 6624 & -1172 & 694 & 114 \\
\hline $\mathrm{H}(23 \mathrm{~A})$ & 6778 & 2537 & -195 & 115 \\
\hline $\mathrm{H}(23 \mathrm{~B})$ & 7534 & 698 & 787 & 115 \\
\hline $\mathrm{H}(24)$ & 3759 & 6311 & 4428 & 113 \\
\hline $\mathrm{H}(25)$ & 8753 & -189 & 6989 & 112 \\
\hline $\mathrm{H}(26)$ & 3953 & 7345 & 7543 & 117 \\
\hline $\mathrm{H}(27 \mathrm{~A})$ & 4021 & 1588 & 4329 & 129 \\
\hline $\mathrm{H}(27 \mathrm{~B})$ & 5268 & -46 & 5293 & 129 \\
\hline $\mathrm{H}(28)$ & 11767 & -768 & 2977 & 132 \\
\hline $\mathrm{H}(29 \mathrm{~A})$ & 6642 & -467 & 3292 & 118 \\
\hline $\mathrm{H}(29 \mathrm{~B})$ & 4909 & 49 & 3015 & 118 \\
\hline $\mathrm{H}(30)$ & 10014 & -2948 & 8334 & 126 \\
\hline $\mathrm{H}(31)$ & 12650 & 1077 & 1094 & 126 \\
\hline $\mathrm{H}(32 \mathrm{~A})$ & 11610 & 4079 & 3586 & 144 \\
\hline $\mathrm{H}(32 \mathrm{~B})$ & 10689 & 4122 & 2512 & 144 \\
\hline $\mathrm{H}(33 \mathrm{~A})$ & 11002 & 1802 & 4848 & 139 \\
\hline $\mathrm{H}(33 \mathrm{~B})$ & 9276 & 2808 & 4391 & 139 \\
\hline $\mathrm{H}(34)$ & 5380 & -1587 & -607 & 131 \\
\hline
\end{tabular}


Table 6S. Torsion angles $\left[^{\circ}\right]$ for compound 19.

\begin{tabular}{|c|c|}
\hline C(4)-P(1)-C(1)-C(12) & $-73.4(5)$ \\
\hline $\mathrm{C}(18)-\mathrm{P}(1)-\mathrm{C}(1)-\mathrm{C}(12)$ & $28.9(6)$ \\
\hline $\mathrm{B}(14)-\mathrm{P}(1)-\mathrm{C}(1)-\mathrm{C}(12)$ & $161.3(5)$ \\
\hline $\mathrm{C}(4)-\mathrm{P}(1)-\mathrm{C}(1)-\mathrm{C}(8)$ & $105.5(5)$ \\
\hline $\mathrm{C}(18)-\mathrm{P}(1)-\mathrm{C}(1)-\mathrm{C}(8)$ & $-152.2(5)$ \\
\hline $\mathrm{B}(14)-\mathrm{P}(1)-\mathrm{C}(1)-\mathrm{C}(8)$ & $-19.8(6)$ \\
\hline$C(6)-P(2)-C(2)-C(21)$ & $-72.6(6)$ \\
\hline $\mathrm{C}(20)-\mathrm{P}(2)-\mathrm{C}(2)-\mathrm{C}(21)$ & $30.5(6)$ \\
\hline $\mathrm{B}(16)-\mathrm{P}(2)-\mathrm{C}(2)-\mathrm{C}(21)$ & $161.2(5)$ \\
\hline $\mathrm{C}(6)-\mathrm{P}(2)-\mathrm{C}(2)-\mathrm{C}(15)$ & $106.6(5)$ \\
\hline $\mathrm{C}(20)-\mathrm{P}(2)-\mathrm{C}(2)-\mathrm{C}(15)$ & $-150.2(5)$ \\
\hline $\mathrm{B}(16)-\mathrm{P}(2)-\mathrm{C}(2)-\mathrm{C}(15)$ & $-19.6(6)$ \\
\hline $\mathrm{C}(1)-\mathrm{P}(1)-\mathrm{C}(4)-\mathrm{C}(13)$ & $-25.8(5)$ \\
\hline $\mathrm{C}(18)-\mathrm{P}(1)-\mathrm{C}(4)-\mathrm{C}(13)$ & $-137.3(5)$ \\
\hline $\mathrm{B}(14)-\mathrm{P}(1)-\mathrm{C}(4)-\mathrm{C}(13)$ & $101.2(5)$ \\
\hline $\mathrm{C}(1)-\mathrm{P}(1)-\mathrm{C}(4)-\mathrm{C}(33)$ & $100.9(5)$ \\
\hline $\mathrm{C}(18)-\mathrm{P}(1)-\mathrm{C}(4)-\mathrm{C}(33)$ & $-10.5(5)$ \\
\hline $\mathrm{B}(14)-\mathrm{P}(1)-\mathrm{C}(4)-\mathrm{C}(33)$ & $-132.1(5)$ \\
\hline $\mathrm{C}(2)-\mathrm{P}(2)-\mathrm{C}(6)-\mathrm{C}(29)$ & $95.1(4)$ \\
\hline $\mathrm{C}(20)-\mathrm{P}(2)-\mathrm{C}(6)-\mathrm{C}(29)$ & $-16.8(5)$ \\
\hline $\mathrm{B}(16)-\mathrm{P}(2)-\mathrm{C}(6)-\mathrm{C}(29)$ & $-137.0(5)$ \\
\hline $\mathrm{C}(2)-\mathrm{P}(2)-\mathrm{C}(6)-\mathrm{C}(23)$ & $-32.8(5)$ \\
\hline $\mathrm{C}(20)-\mathrm{P}(2)-\mathrm{C}(6)-\mathrm{C}(23)$ & $-144.7(5)$ \\
\hline $\mathrm{B}(16)-\mathrm{P}(2)-\mathrm{C}(6)-\mathrm{C}(23)$ & $95.1(6)$ \\
\hline$C(25)-C(3)-C(7)-C(14)$ & $-0.4(8)$ \\
\hline $\mathrm{C}(13)-\mathrm{C}(3)-\mathrm{C}(7)-\mathrm{C}(14)$ & $178.6(5)$ \\
\hline $\mathrm{C}(12)-\mathrm{C}(1)-\mathrm{C}(8)-\mathrm{C}(26)$ & $-0.4(8)$ \\
\hline $\mathrm{P}(1)-\mathrm{C}(1)-\mathrm{C}(8)-\mathrm{C}(26)$ & $-179.4(5)$ \\
\hline $\mathrm{C}(22)-\mathrm{C}(5)-\mathrm{C}(9)-\mathrm{C}(11)$ & $-1.0(8)$ \\
\hline$C(23)-C(5)-C(9)-C(11)$ & $179.5(5)$ \\
\hline $\mathrm{C}(5)-\mathrm{C}(9)-\mathrm{C}(11)-\mathrm{C}(19)$ & $0.4(9)$ \\
\hline $\mathrm{C}(8)-\mathrm{C}(1)-\mathrm{C}(12)-\mathrm{C}(24)$ & $-0.5(8)$ \\
\hline $\mathrm{P}(1)-\mathrm{C}(1)-\mathrm{C}(12)-\mathrm{C}(24)$ & $178.4(5)$ \\
\hline$C(25)-C(3)-C(13)-C(4)$ & $-103.9(6)$ \\
\hline $\mathrm{C}(7)-\mathrm{C}(3)-\mathrm{C}(13)-\mathrm{C}(4)$ & $77.1(7)$ \\
\hline$C(33)-C(4)-C(13)-C(3)$ & $69.8(7)$ \\
\hline $\mathrm{P}(1)-\mathrm{C}(4)-\mathrm{C}(13)-\mathrm{C}(3)$ & $-168.2(4)$ \\
\hline $\mathrm{C}(3)-\mathrm{C}(7)-\mathrm{C}(14)-\mathrm{C}(16)$ & $-0.8(9)$ \\
\hline $\mathrm{C}(21)-\mathrm{C}(2)-\mathrm{C}(15)-\mathrm{C}(17)$ & $0.8(9)$ \\
\hline $\mathrm{P}(2)-\mathrm{C}(2)-\mathrm{C}(15)-\mathrm{C}(17)$ & $-178.5(5)$ \\
\hline$C(7)-C(14)-C(16)-C(30)$ & $1.1(10)$ \\
\hline $\mathrm{C}(2)-\mathrm{C}(15)-\mathrm{C}(17)-\mathrm{C}(31)$ & $-1.9(11)$ \\
\hline $\mathrm{C}(1)-\mathrm{P}(1)-\mathrm{C}(18)-\mathrm{C}(32)$ & $-127.6(5)$ \\
\hline $\mathrm{C}(4)-\mathrm{P}(1)-\mathrm{C}(18)-\mathrm{C}(32)$ & $-16.3(6)$ \\
\hline $\mathrm{B}(14)-\mathrm{P}(1)-\mathrm{C}(18)-\mathrm{C}(32)$ & $101.1(6)$ \\
\hline $\mathrm{C}(9)-\mathrm{C}(11)-\mathrm{C}(19)-\mathrm{C}(34)$ & $-0.3(11)$ \\
\hline$C(2)-P(2)-C(20)-C(27)$ & $-120.7(5)$ \\
\hline $\mathrm{C}(6)-\mathrm{P}(2)-\mathrm{C}(20)-\mathrm{C}(27)$ & $-9.3(5)$ \\
\hline $\mathrm{B}(16)-\mathrm{P}(2)-\mathrm{C}(20)-\mathrm{C}(27)$ & $108.6(6)$ \\
\hline $\mathrm{C}(15)-\mathrm{C}(2)-\mathrm{C}(21)-\mathrm{C}(28)$ & $0.3(9)$ \\
\hline $\mathrm{P}(2)-\mathrm{C}(2)-\mathrm{C}(21)-\mathrm{C}(28)$ & $179.5(5)$ \\
\hline $\mathrm{C}(9)-\mathrm{C}(5)-\mathrm{C}(22)-\mathrm{C}(34)$ & $1.4(9)$ \\
\hline$C(23)-C(5)-C(22)-C(34)$ & $-179.2(6)$ \\
\hline $\mathrm{C}(22)-\mathrm{C}(5)-\mathrm{C}(23)-\mathrm{C}(6)$ & $-93.3(7)$ \\
\hline
\end{tabular}

86.2(7)

$74.0(7)$

$-163.2(5)$

$-1.6(11)$

$1.5(10)$

$1.2(9)$

$-177.8(6)$

$0.7(11)$

$0.3(9)$

$33.1(7)$

$-0.4(11)$

165.6(5)

$38.0(6)$

$-47.0(7)$

$-0.2(10)$

$-0.9(10)$

1.7(12)

$-0.6(12)$

$38.8(7)$

$-48.6(8)$

$162.0(6)$

$34.5(7)$

$0.6(12)$

$-1.2(11)$ 


\section{X-RAY CRYSTALLOGRAPHY REPORT}
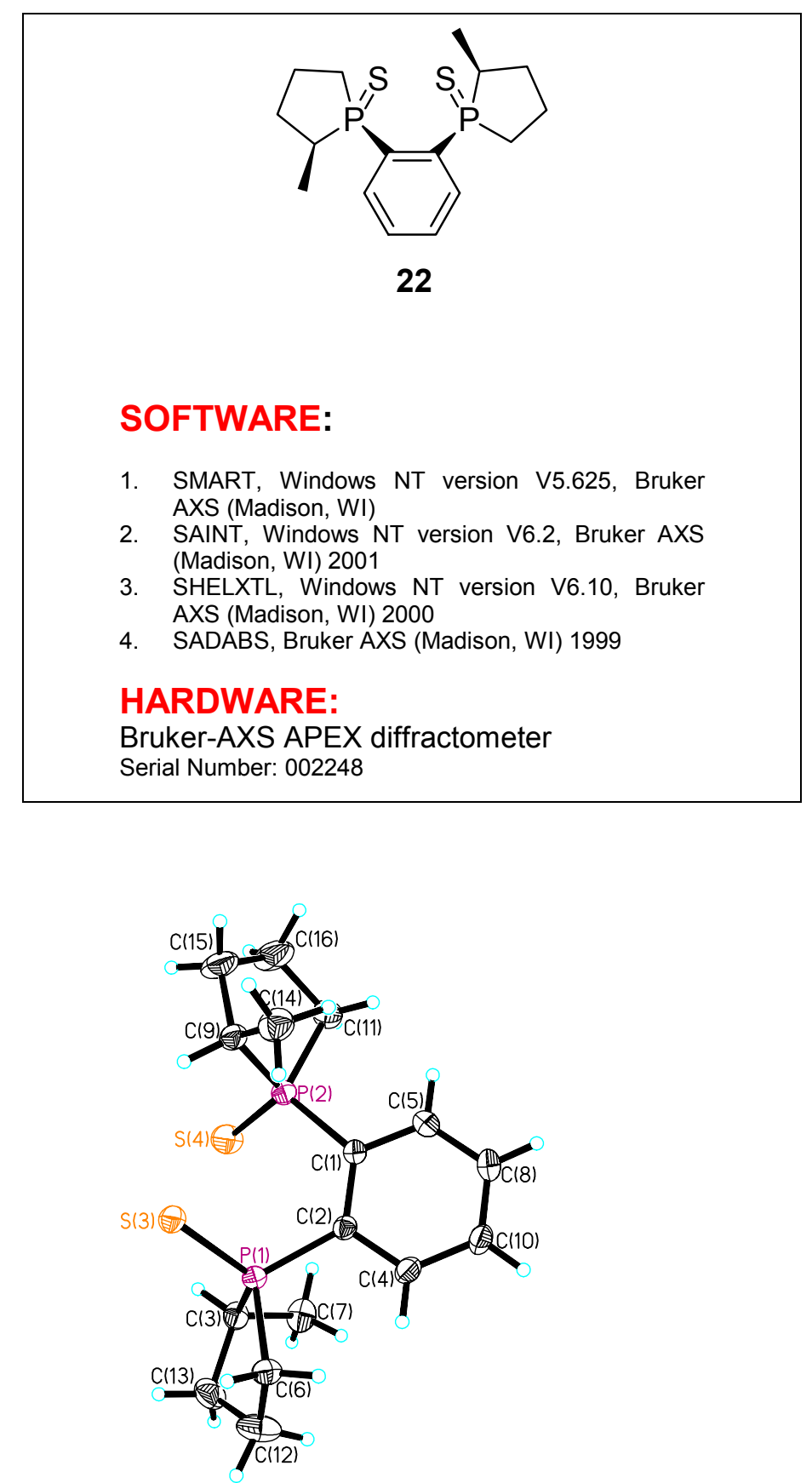

Figure 6S. ORTEP drawing of compound 22. 
Table 8S. Crystal data and structure refinement for compound 22.

Crystallization

Empirical formula

Formula weight

Temperature

Wavelength

Crystal system

Space group

Unit cell dimensions

Volume

Z

Density (calculated)

Absorption coefficient

$\mathrm{F}(000)$

Crystal size

Theta range for data collection

Index ranges

Reflections collected

Independent reflections

Completeness to theta $=28.28^{\circ}$

Absorption correction

Max. and min. transmission

Refinement method

Data / restraints / parameters

Goodness-of-fit on $\mathrm{F}^{2}$

Final R indices [I $>2 \operatorname{sigma}(\mathrm{I})]$

$\mathrm{R}$ indices (all data)

Absolute structure parameter

Extinction coefficient

Largest diff. peak and hole slow evaporation from toluene

C16 H24 P2 S2

342.41

299(2) K

$0.71073 \AA$

Orthorhombic

P2(1)2(1)2(1)

$\mathrm{a}=8.3031(12) \AA \quad \alpha=90^{\circ}$.

$\mathrm{b}=13.3080(19) \AA \quad \beta=90^{\circ}$.

$\mathrm{c}=16.049(2) \AA \quad \gamma=90^{\circ}$.

1773.4(4) $\AA^{3}$

4

$1.283 \mathrm{Mg} / \mathrm{m}^{3}$

$0.470 \mathrm{~mm}^{-1}$

728

$0.16 \times 0.11 \times 0.05 \mathrm{~mm}^{3}$

1.99 to $28.28^{\circ}$.

$-11<=\mathrm{h}<=10,-17<=\mathrm{k}<=17,-21<=1<=21$

15803

$4191[\mathrm{R}(\mathrm{int})=0.0530]$

$97.3 \%$

SADABS

0.9769 and 0.9269

Full-matrix least-squares on $\mathrm{F}^{2}$

4191 / 0 / 184

0.995

$\mathrm{R} 1=0.0612, \mathrm{wR} 2=0.1243$

$\mathrm{R} 1=0.1033, \mathrm{wR} 2=0.1427$

$-0.10(16)$

$0.0000(15)$

0.470 and -0.220 e. $\AA^{-3}$ 
Table 9S. Atomic coordinates $\left(\times 10^{4}\right)$ and equivalent isotropic displacement parameters $\left(\AA^{2} \times 10^{3}\right)$ for compound 22. U(eq) is defined as one third of the trace of the orthogonalized $\mathrm{Uij}^{\mathrm{ij}}$ tensor.

\begin{tabular}{lrrrr}
\hline & $\mathrm{x}$ & $\mathrm{y}$ & $\mathrm{z}$ & $\mathrm{U}(\mathrm{eq})$ \\
\hline $\mathrm{P}(1)$ & & & & \\
$\mathrm{P}(2)$ & $2384(1)$ & $1455(1)$ & $8982(1)$ & $47(1)$ \\
$\mathrm{S}(3)$ & $1527(1)$ & $2444(1)$ & $6953(1)$ & $54(1)$ \\
$\mathrm{S}(4)$ & $244(1)$ & $940(1)$ & $8707(1)$ & $61(1)$ \\
$\mathrm{C}(1)$ & $2754(2)$ & $1221(1)$ & $6734(1)$ & $83(1)$ \\
$\mathrm{C}(2)$ & $2238(5)$ & $3168(3)$ & $7856(2)$ & $52(1)$ \\
$\mathrm{C}(3)$ & $2688(4)$ & $2760(3)$ & $8639(2)$ & $46(1)$ \\
$\mathrm{C}(4)$ & $4143(5)$ & $686(3)$ & $8713(3)$ & $59(1)$ \\
$\mathrm{C}(5)$ & $3367(5)$ & $3392(3)$ & $9227(3)$ & $58(1)$ \\
$\mathrm{C}(6)$ & $2467(6)$ & $4185(3)$ & $7737(3)$ & $73(1)$ \\
$\mathrm{C}(7)$ & $2728(6)$ & $1375(4)$ & $10110(3)$ & $64(1)$ \\
$\mathrm{C}(8)$ & $5595(5)$ & $1326(4)$ & $8479(3)$ & $77(2)$ \\
$\mathrm{C}(9)$ & $3126(7)$ & $4809(4)$ & $8336(4)$ & $80(2)$ \\
$\mathrm{C}(10)$ & $-658(5)$ & $2326(4)$ & $6952(3)$ & $64(1)$ \\
$\mathrm{C}(11)$ & $3597(6)$ & $4411(3)$ & $9080(3)$ & $69(1)$ \\
$\mathrm{C}(12)$ & $1538(7)$ & $3259(4)$ & $6033(3)$ & $74(1)$ \\
$\mathrm{C}(13)$ & $4212(8)$ & $803(5)$ & $10255(4)$ & $103(2)$ \\
$\mathrm{C}(14)$ & $4440(8)$ & $90(4)$ & $9520(3)$ & $85(2)$ \\
$\mathrm{C}(15)$ & $-1513(6)$ & $3127(5)$ & $7463(4)$ & $85(2)$ \\
$\mathrm{C}(16)$ & $-1081(7)$ & $2368(5)$ & $6028(3)$ & $97(2)$ \\
& $121(8)$ & $2903(6)$ & $5553(3)$ & $127(3)$ \\
& & & & \\
\hline
\end{tabular}


Table 10S. Bond lengths $[\AA]$ and angles $\left[^{\circ}\right]$ for compound 22.

$\begin{array}{lclr}\mathrm{P}(1)-\mathrm{C}(3) & 1.835(4) & \mathrm{C}(9)-\mathrm{P}(2)-\mathrm{C}(11) & 93.2(2) \\ \mathrm{P}(1)-\mathrm{C}(6) & 1.835(4) & \mathrm{C}(9)-\mathrm{P}(2)-\mathrm{C}(1) & 111.5(2) \\ \mathrm{P}(1)-\mathrm{C}(2) & 1.839(4) & \mathrm{C}(11)-\mathrm{P}(2)-\mathrm{C}(1) & 108.9(2) \\ \mathrm{P}(1)-\mathrm{S}(3) & 1.9545(15) & \mathrm{C}(9)-\mathrm{P}(2)-\mathrm{S}(4) & 116.64(19) \\ \mathrm{P}(2)-\mathrm{C}(9) & 1.821(5) & \mathrm{C}(11)-\mathrm{P}(2)-\mathrm{S}(4) & 110.25(18) \\ \mathrm{P}(2)-\mathrm{C}(11) & 1.832(5) & \mathrm{C}(1)-\mathrm{P}(2)-\mathrm{S}(4) & 114.26(15) \\ \mathrm{P}(2)-\mathrm{C}(1) & 1.838(4) & \mathrm{C}(5)-\mathrm{C}(1)-\mathrm{C}(2) & 117.5(4) \\ \mathrm{P}(2)-\mathrm{S}(4) & 1.9517(19) & \mathrm{C}(5)-\mathrm{C}(1)-\mathrm{P}(2) & 116.7(3) \\ \mathrm{C}(1)-\mathrm{C}(5) & 1.380(6) & \mathrm{C}(2)-\mathrm{C}(1)-\mathrm{P}(2) & 125.6(3) \\ \mathrm{C}(1)-\mathrm{C}(2) & 1.419(5) & \mathrm{C}(4)-\mathrm{C}(2)-\mathrm{C}(1) & 118.6(4) \\ \mathrm{C}(2)-\mathrm{C}(4) & 1.384(5) & \mathrm{C}(4)-\mathrm{C}(2)-\mathrm{P}(1) & 115.2(3) \\ \mathrm{C}(3)-\mathrm{C}(7) & 1.523(6) & \mathrm{C}(1)-\mathrm{C}(2)-\mathrm{P}(1) & 126.2(3) \\ \mathrm{C}(3)-\mathrm{C}(13) & 1.540(6) & \mathrm{C}(7)-\mathrm{C}(3)-\mathrm{C}(13) & 111.7(4) \\ \mathrm{C}(4)-\mathrm{C}(10) & 1.389(6) & \mathrm{C}(7)-\mathrm{C}(3)-\mathrm{P}(1) & 112.1(3) \\ \mathrm{C}(5)-\mathrm{C}(8) & 1.383(7) & \mathrm{C}(13)-\mathrm{C}(3)-\mathrm{P}(1) & 102.5(3) \\ \mathrm{C}(6)-\mathrm{C}(12) & 1.467(7) & \mathrm{C}(2)-\mathrm{C}(4)-\mathrm{C}(10) & 122.3(4) \\ \mathrm{C}(8)-\mathrm{C}(10) & 1.364(7) & \mathrm{C}(1)-\mathrm{C}(5)-\mathrm{C}(8) & 123.2(4) \\ \mathrm{C}(9)-\mathrm{C}(14) & 1.521(7) & \mathrm{C}(12)-\mathrm{C}(6)-\mathrm{P}(1) & 108.5(4) \\ \mathrm{C}(9)-\mathrm{C}(15) & 1.525(6) & \mathrm{C}(10)-\mathrm{C}(8)-\mathrm{C}(5) & 119.2(4) \\ \mathrm{C}(11)-\mathrm{C}(16) & 1.484(7) & \mathrm{C}(14)-\mathrm{C}(9)-\mathrm{C}(15) & 113.1(5) \\ \mathrm{C}(12)-\mathrm{C}(13) & 1.525(7) & \mathrm{C}(14)-\mathrm{C}(9)-\mathrm{P}(2) & 113.8(3) \\ \mathrm{C}(15)-\mathrm{C}(16) & 1.443(8) & \mathrm{C}(15)-\mathrm{C}(9)-\mathrm{P}(2) & 103.1(3) \\ & & \mathrm{C}(8)-\mathrm{C}(10)-\mathrm{C}(4) & 119.2(4) \\ \mathrm{C}(3)-\mathrm{P}(1)-\mathrm{C}(6) & 94.3(2) & \mathrm{C}(16)-\mathrm{C}(11)-\mathrm{P}(2) & 103.0(4) \\ \mathrm{C}(3)-\mathrm{P}(1)-\mathrm{C}(2) & 110.26(19) & \mathrm{C}(6)-\mathrm{C}(12)-\mathrm{C}(13) & 107.7(5) \\ \mathrm{C}(6)-\mathrm{P}(1)-\mathrm{C}(2) & 109.2(2) & \mathrm{C}(12)-\mathrm{C}(13)-\mathrm{C}(3) & 108.1(4) \\ \mathrm{C}(3)-\mathrm{P}(1)-\mathrm{S}(3) & 118.35(15) & \mathrm{C}(16)-\mathrm{C}(15)-\mathrm{C}(9) & 111.9(5) \\ \mathrm{C}(6)-\mathrm{P}(1)-\mathrm{S}(3) & 110.10(16) & \mathrm{C}(15)-\mathrm{C}(16)-\mathrm{C}(11) & 115.5(4) \\ \mathrm{C}(2)-\mathrm{P}(1)-\mathrm{S}(3) & 112.87(13) & & \end{array}$


Table 11S. Anisotropic displacement parameters $\left(\AA^{2} \times 10^{3}\right)$ for compound 22. The anisotropic displacement factor exponent takes the form: $-2 \pi^{2}\left[\mathrm{~h}^{2} \mathrm{a}^{* 2} \mathrm{U}^{11}+\ldots+2 \mathrm{~h} \mathrm{k} \mathrm{a}^{*} \mathrm{~b}^{*} \mathrm{U}^{12}\right]$

\begin{tabular}{lcccccc}
\hline & $\mathrm{U}^{11}$ & $\mathrm{U}^{22}$ & $\mathrm{U}^{33}$ & $\mathrm{U}^{23}$ & $\mathrm{U}^{13}$ & $\mathrm{U}^{12}$ \\
\hline $\mathrm{P}(1)$ & $45(1)$ & $47(1)$ & $48(1)$ & $2(1)$ & $-5(1)$ & $0(1)$ \\
$\mathrm{P}(2)$ & $64(1)$ & $54(1)$ & $45(1)$ & $0(1)$ & $-5(1)$ & $-4(1)$ \\
$\mathrm{S}(3)$ & $51(1)$ & $68(1)$ & $65(1)$ & $12(1)$ & $-7(1)$ & $-15(1)$ \\
$\mathrm{S}(4)$ & $106(1)$ & $73(1)$ & $70(1)$ & $-15(1)$ & $-6(1)$ & $21(1)$ \\
$\mathrm{C}(1)$ & $57(2)$ & $42(2)$ & $56(2)$ & $0(2)$ & $-10(2)$ & $-2(2)$ \\
$\mathrm{C}(2)$ & $39(2)$ & $46(2)$ & $53(2)$ & $-3(2)$ & $-4(2)$ & $2(2)$ \\
$\mathrm{C}(3)$ & $49(2)$ & $50(2)$ & $78(3)$ & $-6(2)$ & $-4(2)$ & $7(2)$ \\
$\mathrm{C}(4)$ & $57(3)$ & $58(3)$ & $59(3)$ & $-10(2)$ & $-13(2)$ & $-1(2)$ \\
$\mathrm{C}(5)$ & $93(4)$ & $52(3)$ & $73(3)$ & $9(2)$ & $-20(3)$ & $0(3)$ \\
$\mathrm{C}(6)$ & $68(3)$ & $70(3)$ & $54(2)$ & $5(2)$ & $-9(2)$ & $-3(3)$ \\
$\mathrm{C}(7)$ & $48(3)$ & $81(4)$ & $100(4)$ & $-14(3)$ & $13(3)$ & $4(2)$ \\
$\mathrm{C}(8)$ & $99(4)$ & $44(3)$ & $95(4)$ & $-5(3)$ & $-18(3)$ & $-8(3)$ \\
$\mathrm{C}(9)$ & $67(3)$ & $73(3)$ & $51(2)$ & $11(2)$ & $-11(2)$ & $-17(2)$ \\
$\mathrm{C}(10)$ & $74(3)$ & $52(3)$ & $80(3)$ & $-17(3)$ & $-19(3)$ & $-6(2)$ \\
$\mathrm{C}(11)$ & $92(4)$ & $78(3)$ & $51(3)$ & $9(2)$ & $4(3)$ & $-8(3)$ \\
$\mathrm{C}(12)$ & $104(5)$ & $125(5)$ & $79(4)$ & $20(4)$ & $-8(3)$ & $47(4)$ \\
$\mathrm{C}(13)$ & $92(4)$ & $61(3)$ & $103(4)$ & $14(3)$ & $-6(3)$ & $16(3)$ \\
$\mathrm{C}(14)$ & $64(3)$ & $103(4)$ & $88(4)$ & $6(3)$ & $0(3)$ & $-6(3)$ \\
$\mathrm{C}(15)$ & $91(4)$ & $139(5)$ & $60(3)$ & $12(4)$ & $-30(3)$ & $-17(4)$ \\
$\mathrm{C}(16)$ & $127(6)$ & $189(8)$ & $66(4)$ & $48(4)$ & $-36(4)$ & $-58(6)$ \\
& & & & & & \\
& & & & & &
\end{tabular}


Table 12S. Hydrogen coordinates $\left(\begin{array}{ll}x & 10^{4}\end{array}\right)$ and isotropic displacement parameters $\left(\AA^{2} \mathrm{x} 10^{3}\right)$ for compound 22.

\begin{tabular}{|c|c|c|c|c|}
\hline & $\mathrm{x}$ & $\mathrm{y}$ & Z & $\mathrm{U}(\mathrm{eq})$ \\
\hline $\mathrm{H}(3)$ & 3876 & 226 & 8256 & 71 \\
\hline $\mathrm{H}(4)$ & 3679 & 3126 & 9738 & 70 \\
\hline $\mathrm{H}(5)$ & 2164 & 4464 & 7229 & 87 \\
\hline $\mathrm{H}(6 \mathrm{~A})$ & 2829 & 2044 & 10344 & 77 \\
\hline $\mathrm{H}(6 \mathrm{~B})$ & 1825 & 1042 & 10377 & 77 \\
\hline $\mathrm{H}(7 \mathrm{~A})$ & 5749 & 1840 & 8891 & 115 \\
\hline $\mathrm{H}(7 \mathrm{~B})$ & 5414 & 1632 & 7945 & 115 \\
\hline $\mathrm{H}(7 \mathrm{C})$ & 6537 & 909 & 8453 & 115 \\
\hline $\mathrm{H}(8)$ & 3247 & 5492 & 8232 & 96 \\
\hline $\mathrm{H}(9)$ & -950 & 1663 & 7170 & 76 \\
\hline $\mathrm{H}(10)$ & 4067 & 4816 & 9485 & 82 \\
\hline $\mathrm{H}(11 \mathrm{~A})$ & 1420 & 3959 & 6189 & 88 \\
\hline $\mathrm{H}(11 \mathrm{~B})$ & 2523 & 3178 & 5716 & 88 \\
\hline $\mathrm{H}(12 \mathrm{~A})$ & 4128 & 424 & 10770 & 123 \\
\hline $\mathrm{H}(12 \mathrm{~B})$ & 5124 & 1255 & 10299 & 123 \\
\hline $\mathrm{H}(13 \mathrm{~A})$ & 3686 & -465 & 9559 & 103 \\
\hline $\mathrm{H}(13 \mathrm{~B})$ & 5525 & -181 & 9523 & 103 \\
\hline $\mathrm{H}(14 \mathrm{~A})$ & -1122 & 3779 & 7306 & 127 \\
\hline $\mathrm{H}(14 \mathrm{~B})$ & -1305 & 3017 & 8045 & 127 \\
\hline $\mathrm{H}(14 \mathrm{C})$ & -2651 & 3091 & 7363 & 127 \\
\hline $\mathrm{H}(15 \mathrm{~A})$ & -1177 & 1689 & 5814 & 116 \\
\hline $\mathrm{H}(15 \mathrm{~B})$ & -2114 & 2697 & 5960 & 116 \\
\hline $\mathrm{H}(16 \mathrm{~A})$ & -388 & 3480 & 5294 & 153 \\
\hline $\mathrm{H}(16 \mathrm{~B})$ & 498 & 2467 & 5110 & 153 \\
\hline
\end{tabular}


Table 13S. Torsion angles $\left[^{\circ}\right]$ for compound 22 .

$\begin{array}{lc}\mathrm{C}(9)-\mathrm{P}(2)-\mathrm{C}(1)-\mathrm{C}(5) & -93.9(4) \\ \mathrm{C}(11)-\mathrm{P}(2)-\mathrm{C}(1)-\mathrm{C}(5) & 7.4(5) \\ \mathrm{S}(4)-\mathrm{P}(2)-\mathrm{C}(1)-\mathrm{C}(5) & 131.2(4) \\ \mathrm{C}(9)-\mathrm{P}(2)-\mathrm{C}(1)-\mathrm{C}(2) & 91.3(4) \\ \mathrm{C}(11)-\mathrm{P}(2)-\mathrm{C}(1)-\mathrm{C}(2) & -167.3(4) \\ \mathrm{S}(4)-\mathrm{P}(2)-\mathrm{C}(1)-\mathrm{C}(2) & -43.6(4) \\ \mathrm{C}(5)-\mathrm{C}(1)-\mathrm{C}(2)-\mathrm{C}(4) & -1.7(6) \\ \mathrm{P}(2)-\mathrm{C}(1)-\mathrm{C}(2)-\mathrm{C}(4) & 173.0(3) \\ \mathrm{C}(5)-\mathrm{C}(1)-\mathrm{C}(2)-\mathrm{P}(1) & 175.5(4) \\ \mathrm{P}(2)-\mathrm{C}(1)-\mathrm{C}(2)-\mathrm{P}(1) & -9.7(6) \\ \mathrm{C}(3)-\mathrm{P}(1)-\mathrm{C}(2)-\mathrm{C}(4) & -91.9(3) \\ \mathrm{C}(6)-\mathrm{P}(1)-\mathrm{C}(2)-\mathrm{C}(4) & 10.5(4) \\ \mathrm{S}(3)-\mathrm{P}(1)-\mathrm{C}(2)-\mathrm{C}(4) & 133.3(3) \\ \mathrm{C}(3)-\mathrm{P}(1)-\mathrm{C}(2)-\mathrm{C}(1) & 90.8(4) \\ \mathrm{C}(6)-\mathrm{P}(1)-\mathrm{C}(2)-\mathrm{C}(1) & -166.9(4) \\ \mathrm{S}(3)-\mathrm{P}(1)-\mathrm{C}(2)-\mathrm{C}(1) & -44.1(4) \\ \mathrm{C}(6)-\mathrm{P}(1)-\mathrm{C}(3)-\mathrm{C}(7) & -97.7(4) \\ \mathrm{C}(2)-\mathrm{P}(1)-\mathrm{C}(3)-\mathrm{C}(7) & 14.6(4) \\ \mathrm{S}(3)-\mathrm{P}(1)-\mathrm{C}(3)-\mathrm{C}(7) & 146.7(3) \\ \mathrm{C}(6)-\mathrm{P}(1)-\mathrm{C}(3)-\mathrm{C}(13) & 22.2(4) \\ \mathrm{C}(2)-\mathrm{P}(1)-\mathrm{C}(3)-\mathrm{C}(13) & 134.5(3) \\ \mathrm{S}(3)-\mathrm{P}(1)-\mathrm{C}(3)-\mathrm{C}(13) & -93.5(3) \\ \mathrm{C}(1)-\mathrm{C}(2)-\mathrm{C}(4)-\mathrm{C}(10) & 1.0(6) \\ \mathrm{P}(1)-\mathrm{C}(2)-\mathrm{C}(4)-\mathrm{C}(10) & -176.6(4) \\ \mathrm{C}(2)-\mathrm{C}(1)-\mathrm{C}(5)-\mathrm{C}(8) & 0.9(8) \\ & \end{array}$

$\begin{array}{lc}\mathrm{P}(2)-\mathrm{C}(1)-\mathrm{C}(5)-\mathrm{C}(8) & -174.3(5) \\ \mathrm{C}(3)-\mathrm{P}(1)-\mathrm{C}(6)-\mathrm{C}(12) & 2.4(4) \\ \mathrm{C}(2)-\mathrm{P}(1)-\mathrm{C}(6)-\mathrm{C}(12) & -110.8(4) \\ \mathrm{S}(3)-\mathrm{P}(1)-\mathrm{C}(6)-\mathrm{C}(12) & 124.8(4) \\ \mathrm{C}(1)-\mathrm{C}(5)-\mathrm{C}(8)-\mathrm{C}(10) & 0.8(9) \\ \mathrm{C}(11)-\mathrm{P}(2)-\mathrm{C}(9)-\mathrm{C}(14) & -90.0(4) \\ \mathrm{C}(1)-\mathrm{P}(2)-\mathrm{C}(9)-\mathrm{C}(14) & 21.7(4) \\ \mathrm{S}(4)-\mathrm{P}(2)-\mathrm{C}(9)-\mathrm{C}(14) & 155.4(3) \\ \mathrm{C}(11)-\mathrm{P}(2)-\mathrm{C}(9)-\mathrm{C}(15) & 32.9(4) \\ \mathrm{C}(1)-\mathrm{P}(2)-\mathrm{C}(9)-\mathrm{C}(15) & 144.6(4) \\ \mathrm{S}(4)-\mathrm{P}(2)-\mathrm{C}(9)-\mathrm{C}(15) & -81.7(4) \\ \mathrm{C}(5)-\mathrm{C}(8)-\mathrm{C}(10)-\mathrm{C}(4) & -1.6(8) \\ \mathrm{C}(2)-\mathrm{C}(4)-\mathrm{C}(10)-\mathrm{C}(8) & 0.7(8) \\ \mathrm{C}(9)-\mathrm{P}(2)-\mathrm{C}(11)-\mathrm{C}(16) & -31.4(5) \\ \mathrm{C}(1)-\mathrm{P}(2)-\mathrm{C}(11)-\mathrm{C}(16) & -145.4(4) \\ \mathrm{S}(4)-\mathrm{P}(2)-\mathrm{C}(11)-\mathrm{C}(16) & 88.5(4) \\ \mathrm{P}(1)-\mathrm{C}(6)-\mathrm{C}(12)-\mathrm{C}(13) & -27.2(6) \\ \mathrm{C}(6)-\mathrm{C}(12)-\mathrm{C}(13)-\mathrm{C}(3) & 45.9(7) \\ \mathrm{C}(7)-\mathrm{C}(3)-\mathrm{C}(13)-\mathrm{C}(12) & 78.7(6) \\ \mathrm{P}(1)-\mathrm{C}(3)-\mathrm{C}(13)-\mathrm{C}(12) & -41.5(5) \\ \mathrm{C}(14)-\mathrm{C}(9)-\mathrm{C}(15)-\mathrm{C}(16) & 97.8(7) \\ \mathrm{P}(2)-\mathrm{C}(9)-\mathrm{C}(15)-\mathrm{C}(16) & -25.6(7) \\ \mathrm{C}(9)-\mathrm{C}(15)-\mathrm{C}(16)-\mathrm{C}(11) & 2.7(9) \\ \mathrm{P}(2)-\mathrm{C}(11)-\mathrm{C}(16)-\mathrm{C}(15) & 21.4(8) \\ & \end{array}$

